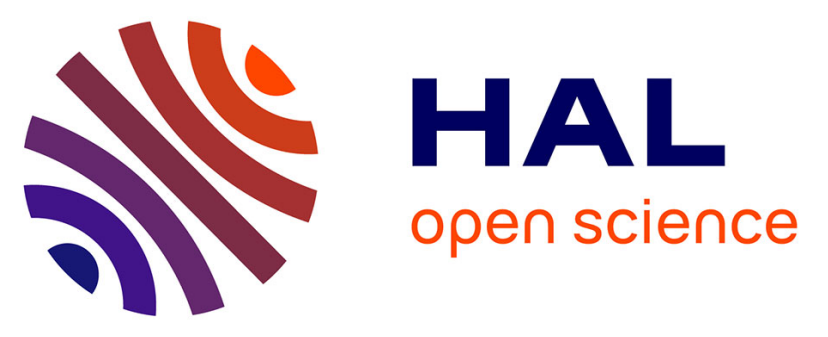

\title{
Temporal trends, sources, and relationships between sediment characteristics and polycyclic aromatic hydrocarbons (PAHs) and polychlorinated biphenyls (PCBs) in sediment cores from the major Seine estuary tributary, France
}

Thomas Gardes, F. Portet-Koltalo, Maxime Debret, Kevin Humbert, Romain Levaillant, Michel Simon, Yoann Copard

\section{- To cite this version:}

Thomas Gardes, F. Portet-Koltalo, Maxime Debret, Kevin Humbert, Romain Levaillant, et al.. Temporal trends, sources, and relationships between sediment characteristics and polycyclic aromatic hydrocarbons (PAHs) and polychlorinated biphenyls (PCBs) in sediment cores from the major Seine estuary tributary, France. Applied Geochemistry, 2020, 122, pp.104749. 10.1016/j.apgeochem.2020.104749 . insu-03188432

\section{HAL Id: insu-03188432 \\ https://hal-insu.archives-ouvertes.fr/insu-03188432}

Submitted on 2 Apr 2021

HAL is a multi-disciplinary open access archive for the deposit and dissemination of scientific research documents, whether they are published or not. The documents may come from teaching and research institutions in France or abroad, or from public or private research centers.
L'archive ouverte pluridisciplinaire HAL, est destinée au dépôt et à la diffusion de documents scientifiques de niveau recherche, publiés ou non, émanant des établissements d'enseignement et de recherche français ou étrangers, des laboratoires publics ou privés. 


\section{Journal Pre-proof}

Temporal trends, sources, and relationships between sediment characteristics and polycyclic aromatic hydrocarbons (PAHs) and polychlorinated biphenyls (PCBs) in sediment cores from the major Seine estuary tributary, France

Thomas Gardes, Florence Portet-Koltalo, Maxime Debret, Kevin Humbert, Romain Levaillant, Michel Simon, Yoann Copard

PII:

$$
\text { S0883-2927(20)30241-9 }
$$

DOI:

$$
\text { https://doi.org/10.1016/j.apgeochem.2020.104749 }
$$

Reference: $\quad$ AG 104749

To appear in: Applied Geochemistry

Received Date: 4 June 2020

Revised Date: 27 August 2020

Accepted Date: 27 August 2020

Please cite this article as: Gardes, T., Portet-Koltalo, F., Debret, M., Humbert, K., Levaillant, R., Simon, M., Copard, Y., Temporal trends, sources, and relationships between sediment characteristics and polycyclic aromatic hydrocarbons (PAHs) and polychlorinated biphenyls (PCBs) in sediment cores from the major Seine estuary tributary, France, Applied Geochemistry, https://doi.org/10.1016/ j.apgeochem.2020.104749.

This is a PDF file of an article that has undergone enhancements after acceptance, such as the addition of a cover page and metadata, and formatting for readability, but it is not yet the definitive version of record. This version will undergo additional copyediting, typesetting and review before it is published in its final form, but we are providing this version to give early visibility of the article. Please note that, during the production process, errors may be discovered which could affect the content, and all legal disclaimers that apply to the journal pertain.

(c) 2020 Elsevier Ltd. All rights reserved. 


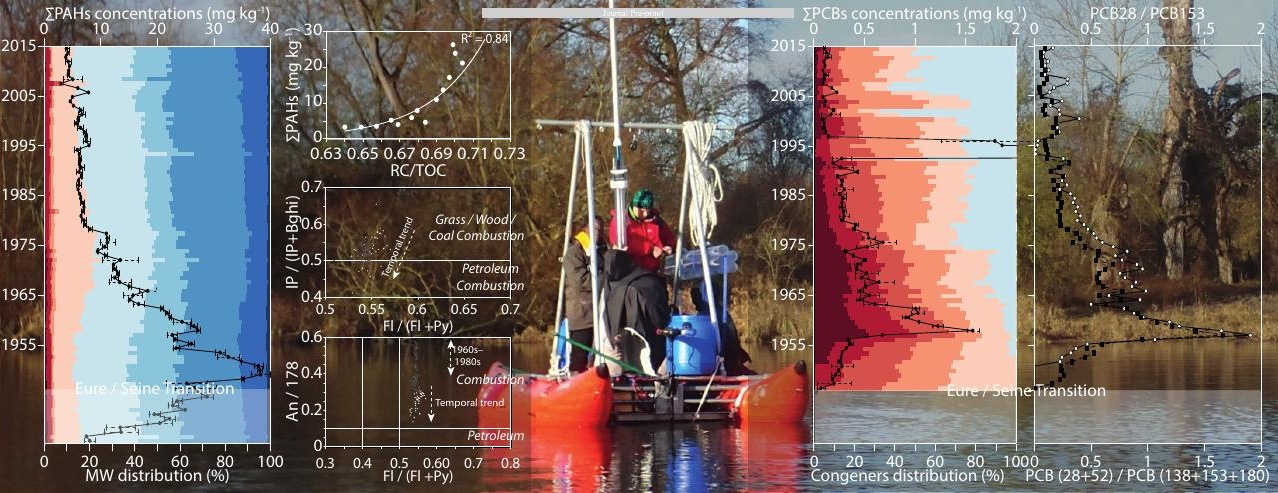


1 Temporal trends, sources, and relationships between sediment

2 characteristics and polycyclic aromatic hydrocarbons (PAHs) and polychlorinated biphenyls (PCBs) in sediment cores from the

4 major Seine estuary tributary, France

5

6

Thomas Gardes ${ }^{1,2, *}$, Florence Portet-Koltalo ${ }^{2}$, Maxime Debret ${ }^{1}$, Kevin Humbert ${ }^{1,2}$, Romain Levaillant $^{1}$, Michel Simon ${ }^{1}$, Yoann Copard ${ }^{1}$

${ }^{1}$ Normandie Univ, Rouen, UNIROUEN, UNICAEN, CNRS, M2C, 76000 Rouen, France.

${ }^{2}$ Normandie Univ, Rouen, UMR CNRS 6014 COBRA, 55 Rue Saint Germain, 27000 Evreux, France.

*Corresponding author: thomas.gardes1@univ-rouen.fr

\section{Abstract}

Temporal trends in polycyclic aromatic hydrocarbons (PAHs) and polychlorinated biphenyls (PCBs) were reconstructed from sediment cores collected from two ponds downstream of the Eure River watershed. PAHs exhibited a positive correlation with fine fractions, but mainly with the refractory organic carbon measured in the sediments, which suggests PAH inputs from materials largely composed of refractory carbon (e.g. soot). Since the 1940s, PAH concentrations have ranged between $2.93-38.20$ and $2.27-28.20 \mathrm{mg} \mathrm{kg}^{-1}$. Based on the temporal distribution of isomers and diagnostic ratios, the PAHs in the sediments were found to be predominantly of pyrogenic origin, particularly in the 1940s-1960s, when PAH levels were particularly high. PCBs also showed an affinity with the fine fraction and with refractory organic carbon, albeit less so than PAHs. Since the 1940s, PCB concentrations ranged between $0.02-1.57$ and $0.09-1.60 \mathrm{mg} \mathrm{kg}^{-1}$. The recorded PCB temporal trends were mainly 
associated with the production, consumption, and banning of these chemicals in France.

According to the temporal distribution of PCB congeners, high levels in the 1950s-1970s were linked to "technical mixture" discharges into waterways, which were mainly composed of "low chlorinated congeners", whereas PCB levels after the 1970s were of atmospheric origin.

\section{Keywords}

Temporal trends; PAHs; PCBs; sediment cores; refractory organic carbon

\section{Introduction}

Persistent organic pollutants (POPs) are ubiquitous environmental contaminants that began to be widely produced and consumed after the Second World War (Bigus et al., 2014). These organic compounds are not only very stable and therefore difficult to degrade or biodegrade, but are also often very toxic (Bigus et al., 2014). Additionally, these compounds are generally highly hydrophobic (Wan et al., 2011; Tobiszewski and Namieśnik, 2012) and therefore tend to bind to suspended particulate matter (SPM) transported by rivers, thereby accumulating in aquatic systems (Zennegg et al., 2007).

Polycyclic aromatic hydrocarbons (PAHs) are POPs that are released into the environment both from natural (e.g. fires, volcanoes) and anthropogenic sources (e.g. incomplete combustion processes, petroleum product leakage), the latter becoming predominant in the twentieth century (Bigus et al., 2014). PAHs enter aquatic environments via atmospheric deposition, wastewater discharge from industrial sites, or surface runoff from urban or industrial areas (Heemken et al., 2000). Petrogenic PAHs (i.e. those derived from petroleum products or kerogen maturation) are generally emitted directly into aquatic environments, 
whereas pyrogenic PAHs (i.e. those derived from combustion processes) can be emitted directly into aquatic environments (e.g. from use or release of coal tar, creosote, manufactured gas plant wastes and leaking or improperly disposed of used motor oil) or first emitted into the atmosphere and subsequently enter aquatic environments (Tobiszewski and Namieśnik, 2012). Atmospheric PAH emissions may be associated with particles; alternatively, these compounds may occur in the gaseous phase when emitted at high temperatures, after which they may condense onto particles upon cooling (Tobiszewski and Namieśnik, 2012). PAHs are generally adsorbed onto fine particles but can be transferred from fine to coarser particles through aggregation over time (Oliveira et al., 2011). PAHs preferentially accumulate in sediments after entering streams due to their hydrophobicity and generally undergo few or no changes over many years (Hatzinger and .Alexander, 1995; Douglas et al., 1996; Page et al., 1999). Unlike light PAHs (2-3-ring PAHs), which are more volatile and metabolisable by microorganisms, heavy PAHs (4-6-ring PAHs) are considered to be relatively stable within sediment matrices. This accumulation in the sediment can be modulated by the sediment's composition and characteristics (e.g. particle size, organic carbon $\left(\mathrm{C}_{\text {org }}\right)$ content) (Means et al., 1980; Tobiszewski and Namieśnik, 2012). Notably, PAHs in streams are preferentially adsorbed onto fine particles (Karickhoff et al., 1979), and thus fine particle sedimentation leads to the concurrent sedimentation of associated PAHs. PAHs are preferentially adsorbed onto $\mathrm{C}_{\text {org-rich }}$ matrices, and therefore the $\mathrm{C}_{\text {org }}$ content in the sediment matrix controls PAHs behaviour in sediments (Karickhoff et al., 1979; Zhang et al., 2004; Shi et al., 2007). Moreover, a significant correlation between PAHs and $\mathrm{C}_{\text {org }}$ (and soot) levels tends to occur when PAHs are derived mainly from atmospheric inputs (Tsapakis et al., 2003).

Polychlorinated biphenyls (PCBs) are synthetic compounds that were used in various industrial activities due to their high thermal stability and dielectric properties. Their widespread use, especially after the Second World War, has therefore led to a significant 
accumulation of these compounds in the environment (Piérard et al., 1996; Breivik et al., 2002). In France, the use of PCBs was banned in 1987 due to their proven toxicity (Decree 87-59, 1987). The transport of PCBs from terrestrial sources to aquatic environments may result from direct inputs, following leakage from systems containing them (Abarnou et al., 1987; Duursma et al., 1989), or from atmospheric deposition following volatilization (Chevreuil et al., 1989; Quémerais et al., 1994; Granier and Chevreuil, 1997). In the atmosphere, PCBs are predominantly present in their gaseous phase, after which they bind to particles through atmospheric deposition (Granier and Chevreuil, 1997). Similar to PAHs, PCBs are very chemically stable and are only minimally transformed during the sedimentation process. Due to their lipophilic nature, PCBs accumulate in soils and sediments by binding to fine particles that are rich in organic matter $(\mathrm{OM})$ and have a high surface-tovolume ratio (Karickhoff et al., 1979; Gschwend and Wu, 1985). Nevertheless, Piérard et al. (1996) observed that the affinity of PCBs to OM cannot fully explain the distribution of sediment PCB concentrations, and that particle size is the major factor explaining their distribution. Specifically, PCBs generally accumulate in fine particles, especially highly chlorinated PCBs, which have a particular affinity for fine fractions $(<63 \mu \mathrm{m})$, whereas low chlorinated PCBs have more affinity for coarse fractions (> $63 \mu \mathrm{m}$ ) (Piérard et al., 1996; Salvadó et al., 2013).

Based on sediment cores collected in accumulation areas (e.g. dams, floodplains, ponds), the temporal trends of PAHs and PCBs can be reconstructed (Sanders et al., 1992; Van Metre et al., 1997; Budzinski et al., 1997; Bertrand et al., 2015; Cai et al., 2016). Thus, it is possible to reconstruct the contamination trends of a watershed, generally in relation to the intensification of significant anthropogenic activities since the industrial revolution (i.e. over the past $\sim 150$ years). Sediment deposits typically provide insights into multiple contaminant sources and therefore it is necessary to discriminate sources by analysing the distribution of PAH isomers 
and PCB congeners over time via measured-concentration diagnostic ratios (Budzinski et al., 1997; Yunker et al., 2002; Franců et al., 2010; Cai et al., 2016).

The Seine River watershed is among the most heavily impacted watersheds in Europe (Meybeck, 2002) and therefore the Seine River has been afflicted with substantial heavy metal (Le Cloarec et al., 2011) and organic contaminant (Lorgeoux et al., 2016) burdens. Although many studies have examined POP contaminations in water, SPM, and sediments in the Seine River (Chevreuil et al., 1990; Chevreuil and Granier, 1991; Chevreuil et al., 1998; Blanchard et al., 2007; Lorgeoux et al., 2016), few studies have focused on its tributaries (e.g. the Marne River) (Chevreuil and Granier, 1991; Ollivon et al., 2002) or the Seine estuary (Abarnou et al., 1987; Marchand, 1989; Van Metre et al., 2008). Regarding the latter, only the works of Van Metre et al. (2008) have focused on sedimentary archives downstream of the estuary; however, contamination sources in this area appear to be intra-estuarine.

The main Seine estuary tributary is the Eure River. Moreover, the Eure River watershed was recently found to carry significant heavy metal burdens since the 1940 s, which may have impacted the sediment quality of the Seine estuary (Gardes et al., 2020a, 2020b). Therefore, this study aimed to establish a link between sediment deposit characteristics and POPs, as well as to reconstruct the temporal trends in PAHs and PCBs accumulation based on sediment cores collected downstream of the Eure River watershed. The distribution of some PAH isomers and PCB congeners was also studied to determine contaminant sources and the evolution of these sources over time.

\section{Materials and Methods}

\subsection{Description of core sites}


The Eure River (watershed: $6017 \mathrm{~km}^{2}$; mean annual flow: $22.13 \pm 6.69 \mathrm{~m}^{3} \mathrm{~s}^{-1}$ ) is one of the largest tributaries of the Seine River (i.e. only surpassed by the Yonne, Marne, and Oise rivers) and the main contributing river in its estuarine section (Fig. 1A). Les Damps Pond (average depth: $50 \mathrm{~cm}$; area: < $1 \mathrm{ha}$ ) and Martot Pond (area: $\sim 7$ ha) are located approximately $10 \mathrm{~km}$ and less than $1 \mathrm{~km}$ upstream of the Eure River outlet, respectively (Fig. 1B). Unlike Les Damps Pond, Martot Pond is affected by the Seine estuary during tidal flows through the Eure River outlet. Moreover, Martot Dam, located 200 m downstream of the Martot Pond, prevented tidal flows (for tidal coefficients lower than 70) until its removal in October 2017. Sediment cores were collected using a UWITEC $®$ gravity core and $90 \mathrm{~mm}$ diameter PVC tubes. The water-sediment interface was preserved for each coring. For Les Damps Pond, sediment cores DAM15-02 and DAM17-02 were collected in January 2015 and January 2017, respectively (Fig. 1C; Table 1). For Martot Pond, sediment cores MAR15-01 and MAR16-02 were collected in January 2015 and February 2016, respectively (Fig. 1D; Table 1). This study was conducted on sediment cores from two accumulation zones to (i) ensure that the recorded temporal trends were representative of a global signal and (ii) determine whether sedimentation in Martot pond was impacted by inputs from the Seine estuary.

\subsection{Grain size and total organic carbon analysis}

Grain size distribution was measured by laser diffraction (LS 13320 Particle Size Analyser Beckman Coulter $\left.{ }^{\mathrm{TM}}\right)$. The measurements were conducted every $\mathrm{cm}$ by integrating $1 \mathrm{~cm}$ on the MAR15-01 and DAM15-02 cores.

Sediment cores were analysed using Rock-Eval 6 (RE6) pyrolysis ("Turbo" model RE6 pyrolyzer; ISTO laboratory, University of Orléans; see details in Copard et al. (2006)). Total organic carbon content (TOC; \%) was measured and OM quality was determined by 
measuring the hydrogen index (HI; i.e. indicator of the hydrogen richness; $\mathrm{mg} \mathrm{HC} \mathrm{g}^{-1} \mathrm{TOC}$ ) and oxygen (OI; indicator of the degree of oxidation of the $\mathrm{OM} ; \mathrm{mg} \mathrm{O}_{2} \mathrm{~g}^{-1}$ TOC) (Lafargue et al., 1998; Carrie et al., 2012). Additionally, the residual carbon content (RC; \%), which corresponds to the refractory $\mathrm{C}_{\text {org }}$ (obtained during the oxidation phase), was also measured (Lafargue et al., 1998). The measurements were conducted on the MAR15-01 and DAM17-02 cores at $1-$ and $2-\mathrm{cm}$ intervals, respectively.

\subsection{Particulate PAHs/PCBs extraction, analysis and quality control and assurance}

Each sediment core segment was freeze-dried, crushed, and stored at $-25{ }^{\circ} \mathrm{C}$. Afterwards, PAHs and PCBs extractions were performed using microwave-assisted extraction (MAE) (MarsX, CEM Corporation). Approximately 2-3 g of sub-samples were taken from each dried portion of the sediment cores and spiked with $15 \mu \mathrm{L}$ of surrogate standards (perdeuterated fluoranthene and benzo[a]pyrene, and PCB156 at $100 \mathrm{mg} \mathrm{L}^{-1}$ ). Each sub-sample was extracted in duplicate with $40 \mathrm{~mL}$ of a toluene:acetone $1: 1$ (v:v) mixture at $130{ }^{\circ} \mathrm{C}$ for $30 \mathrm{~min}$ $(1,200 \mathrm{~W})$. The extracts were filtered through $0.2-\mu \mathrm{m}$ PTFE filters, evaporated, and reconstituted in $1.5 \mathrm{~mL}$ toluene. Each extract $(990 \mu \mathrm{L})$ was mixed with $10 \mu \mathrm{L}$ of two internal standards (perdeuterated phenanthrene and perylene at $100 \mathrm{mg} \mathrm{L}^{-1}$ ), after which $1 \mu \mathrm{L}$ of the resulting mixture was injected (splitless mode, $285^{\circ} \mathrm{C}$ ) into a gas chromatographer $(6850$ series, Agilent), coupled with a mass spectrometer (5975C series). The separation was performed using a $60 \mathrm{~m} \times 0.25 \mathrm{~mm}$ i.d. DB-5MS capillary column $(0.25 \mu \mathrm{m}$ film thickness; $\mathrm{J} \& \mathrm{~W}$ Scientific), with helium as the carrier gas $\left(1.4 \mathrm{~mL} \mathrm{~min}^{-1}\right)$. The oven temperature was programmed at $60{ }^{\circ} \mathrm{C}$ for $1.2 \mathrm{~min}$, increased to $190{ }^{\circ} \mathrm{C}\left(40{ }^{\circ} \mathrm{C} \mathrm{min}^{-1}\right)$ and then to $305{ }^{\circ} \mathrm{C}\left(6{ }^{\circ} \mathrm{C}\right.$ $\min ^{-1}$ ). The MS detector operated at $70 \mathrm{eV}$. Quantification was based on selected ion monitoring to improve sensitivity. The extraction method was validated using a certified 
reference sediment (CNS391, Sigma-Aldrich). Mean recoveries $(n=5)$ were in the 86.3$125.8 \%$ range for the 16 priority PAHs (US EPA, 2015) and in the 81.9-113.6\% range for the 6 studied PCBs. Table 2 summarizes all PAHs and PCBs studied herein.

\section{Results and discussion}

3.1. Sedimentology characteristics of the sediment cores

The sediment deposits in Martot Pond are characterised by two sedimentary facies, as previously described by Gardes et al. (2020b). The "Seine Unit" facies corresponds to sediment deposits from the Seine River watershed until the early 1940s, when Martot Pond was connected to the Seine channel. The grain size distribution exhibited a low $\mathrm{D}_{50}\left(\mathrm{D}_{50}=\right.$ $13.8 \pm 7.0 \mu \mathrm{m})$, the TOC content $\left(\mathrm{TOC}_{\text {mean }}=1.75 \pm 0.33 \%\right)$ was low, $\mathrm{HI}\left(\mathrm{HI}_{\text {mean }}=147 \pm 24\right.$

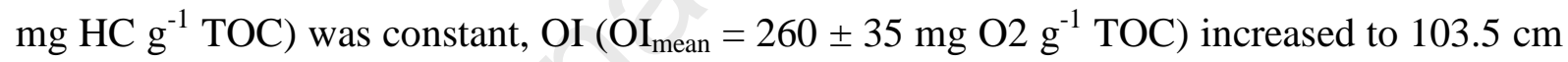
followed by a decrease, and the average RC/TOC was $0.76 \pm 0.01$. The "Eure Unit" facies, for which an age model has been established, corresponds to the Eure River inputs since the 1940s, with a sedimentation rate of $12.73 \pm 2.2 \mathrm{~mm} \mathrm{y}^{-1}$ (Gardes et al., 2020b). For this facies, the grain size distribution was centred around a $\mathrm{D}_{50}$ of $33.9 \pm 7.8 \mu \mathrm{m}$ and the TOC content $\left(\mathrm{TOC}_{\text {mean }}=3.88 \pm 1.49 \%\right)$ increased towards the surface, with high contents $(\mathrm{TOC}=8.26 \pm$

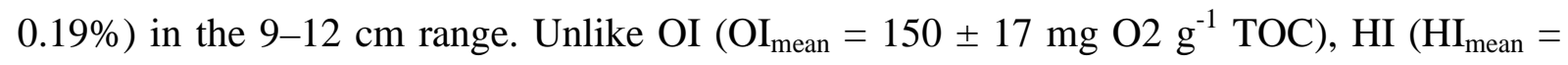
$279 \pm 23 \mathrm{mg} \mathrm{HC} \mathrm{g}^{-1}$ TOC) increased from the transition between the two facies. RC/TOC $\left(\mathrm{RC} / \mathrm{TOC}_{\text {mean }}=0.70 \pm 0.02\right)$ decreased from the interface between the two facies and continued to decrease towards the surface (Fig. 2).

The sediment deposits in Les Damps Pond are also referred to as the "Eure Unit" facies, and correspond to the Eure River inputs since the 1940s, with a sedimentation rate of $12.2 \mathrm{~mm} \mathrm{y}^{-1}$ 
(Gardes et al., 2020b). These sediment deposits are characterised by a grain size distribution centred around a $\mathrm{D}_{50}$ of $29.5 \pm 6.7 \mu \mathrm{m}$, comparable to that measured for the "Eure Unit" facies in Martot Pond, with a constant TOC content $\left(\mathrm{TOC}_{\text {mean }}=5.36 \pm 0.47 \%\right)$ that is slightly higher than that of Martot Pond. HI $\left(\mathrm{HI}_{\text {mean }}=302 \pm 23 \mathrm{mg} \mathrm{HC} \mathrm{g}^{-1} \mathrm{TOC}\right)$ and $\mathrm{OI}\left(\mathrm{OI}_{\text {mean }}=145 \pm 10\right.$ $\left.\mathrm{mg} \mathrm{O} 2 \mathrm{~g}^{-1} \mathrm{TOC}\right)$ showed a slight increase towards the surface. $\mathrm{RC} / \mathrm{TOC}\left(\mathrm{RC} / \mathrm{TOC}_{\text {mean }}=0.68\right.$ \pm 0.02 ) decreased towards the surface, similar to our observations in Martot Pond (Fig. 2).

In Martot and Les Damps ponds, HI and OI for the "Eure Unit" facies suggested a mix aquatic/terrestrial origin (Gardes et al., 2020b) and the mean RC/TOC values were similar and comparable to those measured in the surface sediments of other European rivers (e.g. the Danube, Elbe, Ebro, and Meuse rivers; Poot et al. (2014)). For both ponds, the sedimentation rates were found to be high (e.g. $\geq 10 \mathrm{~mm} \mathrm{y}^{-1}$ ), and therefore it is unlikely that the sediments are affected by early diagenesis processes (Van Metre et al., 1997; Callender, 2000).

\subsection{Relationships between PAHs, PCBs, and sediment characteristics}

In Martot Pond, PAH and PCB concentrations were determined on the MAR16-02 core (Sections 3.3 and 3.4), whereas the grain size distribution and TOC contents (and associated OM parameters) were determined on the MAR15-01 core (Section 3.1). In Les Damps Pond, PAH and PCB concentrations were determined on the DAM17-02 core (Sections 3.3 and 3.4), as well as TOC contents, whereas grain size distribution was determined on the DAM15-02 core. Therefore, the measurements were averaged over decades for each core to determine the correlations between PAH and PCB contents and grain size or OM in both ponds.

In both ponds, total PAH concentrations ( $\mathrm{PAHs}$ ) and light (2-3-ring) or heavy (4-6-ring) PAHs exhibited weak positive correlations with the clay fraction $(<2 \mu \mathrm{m})(0.28<\mathrm{R}<0.39$ and $0.23<\mathrm{R}<0.33$ for Martot and Les Damps ponds, respectively) (Fig. 3A). In Les Damps 
Pond, PAHs showed strong positive correlations with the fine fraction $(<63 \mu \mathrm{m})$, particularly with the silt fraction $(2-63 \mu \mathrm{m})(0.74<\mathrm{R}<0.8)$. Finally, PAHs showed negative correlations with the coarse fraction $(>63 \mu \mathrm{m})$ in Les Damps Pond $(-0.69<\mathrm{R}<-0.75)$. Therefore, PAHs tend to bind more strongly to the fine fraction (Karickhoff et al., 1979; Fernandes et al., 1997; Shi et al., 2007), and more specifically to the silt fraction in Les Damps Pond, as previously demonstrated elsewhere by Ab Razak et al. (1996) with sediment cores from the Kinnickinnic River (US) and Burgess et al. (2001) with surface sediments collected in the Narragansett Bay estuary (US), or to the clay fraction in the Martot Pond, as also reported by Zhang et al. (2004) with surficial sediments of Deep Bay (China).

PAHs were negatively correlated with (i) the TOC in Martot Pond $(-0.63<\mathrm{R}<-0.80)$, (ii) HI $(-0.48<\mathrm{R}<-0.77$ and $-0.89<\mathrm{R}<-0.93$ for Martot and Les Damps ponds, respectively) and OI $(-0.27<\mathrm{R}<-0.76$ and $-0.55<\mathrm{R}<-0.6$ for Martot and Les Damps ponds, respectively). However, $\sum$ PAHs showed strong positive correlations with the RC/TOC ratio ( $R=0.86$ and $R=0.95$ for Martot and Les Damps ponds, respectively) (Fig. 3A).

The distribution of PAHs in the sediment is thus partly controlled by the presence of fine particles, but more predominantly controlled by the presence of refractory $\mathrm{C}_{\text {org }}$. Moreover, in Martot Pond, the correlation between PAHs and RC/TOC tended to increase with the molar mass of the PAHs (from $\mathrm{R}=0.53$ for 2-ring PAHs to $\mathrm{R}=0.91$ for 6-ring PAHs). However, this trend was not observed in Les Damps Pond, where the correlation between PAHs and $\mathrm{RC} / \mathrm{TOC}$ was very strong regardless of molar mass $(0.91<\mathrm{R}<0.95)$. A correlation between the PAHs and the proportion of refractory $\mathrm{C}_{\text {org }}$ (i.e. RC/TOC) would thus demonstrate that part of the PAHs was bound to refractory carbonaceous compounds. Such an affinity has been previously identified, albeit from the RC (\%) (Poot et al., 2014) and not from the RC/TOC ratio. Additionally, PAHs showed a correlation with the RC/TOC ratio regardless of ring number, but only in Les Damps Pond (Fig. 3B). However, this trend remains to be confirmed, 
especially to determine whether the proportion of refractory $\mathrm{C}_{\text {org }}$ is indeed the limiting factor, as suggested by the observed correlations.

PCBs showed positive correlations with the fine fraction (clay + silt $)(0.20<\mathrm{R}<0.56$ and $0.16<\mathrm{R}<0.71$ for Martot and Les Damps ponds, respectively) and negative correlations with the coarse fraction $(-0.20<\mathrm{R}<-0.56$ and $-0.16<\mathrm{R}<-0.71$ for Martot and Les Damps ponds, respectively) (Fig. 3A). A positive correlation of $\mathrm{PCBs}$ with the fine fraction suggests an affinity of PCBs for fine particles, but no clear trends (e.g. as a function of PCB chlorination degree) were evident. Moreover, Piérard et al. (1996) demonstrated that low-chlorinated PCBs showed an affinity for the coarse fraction, which was not observed in our study. PCBs also showed negative correlations with TOC in Martot Pond $(-0.69<\mathrm{R}<-0.79)$, as well as with HI $(-0.35<\mathrm{R}<-0.79$ and $-0.27<\mathrm{R}<-0.92$ for Martot and Les Damps ponds, respectively) and OI $(-0.37<\mathrm{R}<-0.72$ and $-0.15<\mathrm{R}<-0.79$ for Martot and Les Damps ponds, respectively) (Fig. 3A). However, the $\sum$ PCBs showed positive correlations with the $\mathrm{RC} / \mathrm{TOC}$ ratio $(\mathrm{R}=0.68$ and $\mathrm{R}=0.79$ for Martot and Les Damps ponds, respectively). The distribution of PCBs in sediments is thus partly controlled by fine particles and refractory $\mathrm{C}_{\text {org }}$, but the affinity between PCBs and refractory $\mathrm{C}_{\text {org }}$ is generally less marked than for PAHs.

\subsection{PAHs in sediment cores}

\subsubsection{General PAH trends in sediment cores}

Total PAH concentrations were measured for the MAR16-02 and DAM17-02 cores (Fig. 4) For the MAR16-02 core Seine Unit $(78-90 \mathrm{~cm})$, PAH concentrations ranged from 7.43 to $28.8 \mathrm{mg} \mathrm{kg}^{-1}\left(\mathrm{PAH}_{\text {mean }}=19.9 \pm 1.47 \mathrm{mg} \mathrm{kg}^{-1}\right)$ and showed a constant increase towards the Eure Unit. For the Eure Unit of the MAR16-02 and DAM17-02 cores, concentrations ranged 
between $2.93-38.20 \mathrm{mg} \mathrm{kg}^{-1}\left(\mathrm{PAH}_{\text {mean }}=12.70 \pm 0.51 \mathrm{mg} \mathrm{kg}^{-1}\right)$ and $2.27-28.20 \mathrm{mg} \mathrm{kg}{ }^{-1}$ $\left(\mathrm{PAH}_{\text {mean }}=11.10 \pm 0.89 \mathrm{mg} \mathrm{kg}^{-1}\right)$, respectively. For the MAR16-02 core, the upward trend measured in the Seine Unit continued after the transition to the Eure Unit, reaching a peak of $38.20 \pm 1.70 \mathrm{mg} \mathrm{kg}^{-1}$ in the late 1940s. For the DAM17-02 core, high concentrations were measured during the 1940s-1950s and two peaks were observed at $28.20 \pm 2.44$ and $26.10 \pm$ $0.58 \mathrm{mg} \mathrm{kg}^{-1}$. PAH concentrations began to decrease from the 1960 s to the early $1980 \mathrm{~s}$. For the most recent deposition (post-1980s), concentrations were largely constant, ranging between 4 and $6 \mathrm{mg} \mathrm{kg}^{-1}$ (MAR16-02: $5.87 \pm 0.26 \mathrm{mg} \mathrm{kg}^{-1}$; DAM17-02: $4.00 \pm 0.33 \mathrm{mg} \mathrm{kg}^{-1}$ ).

The two sediment records showed high concentrations during the 1940s-1960s, following the trends determined for the Seine River (Lorgeoux et al., 2016). Notably, although the maximum levels measured by these authors were more than twice those measured for the lower reaches of the Eure River, the maximum values obtained in the Eure River were within the same order of magnitude as the concentrations measured in sediments collected downstream of the Marne River watershed (Ollivon et al., 2002). Moreover, the observed maxima were higher than those measured in other French watersheds, such as the Loire River watershed (Bertrand et al., 2015). Nonetheless, the Eure River watershed and the Eure River flow were $\sim 13$ and 30 times lower than those of the Seine River and $\sim 20$ and 50 times lower than those of the Loire River, showing the severity of PAH contamination in the Eure River watershed, particularly during the 1940s-1960s. Moreover, the obtained maxima were also higher than those measured in surface sediments of several large European lakes (Fernández et al., 1999), SPM from several large French and European rivers (Rhone, Tamar, Scheldt and Rhine rivers; Fernandes et al. (1999)), or in sediments from Canadian lakes located near an oil sands mining site (Ahad et al., 2015). Concentrations for the most recent deposits are comparable to those determined for recent sediment deposits in the Seine Basin (Lorgeoux et al., 2016), SPM collected in the Seine River (Gasperi et al., 2009), or concentrations 
measured in the Loire River watershed since the late 1980s (Bertrand et al., 2015). In addition, some PAH concentrations recorded during the 1940s-1960s exceeded the probable effect concentrations (PECs; equal to $22.8 \mathrm{mg} \mathrm{kg}^{-1}$ for total PAHs) defined by MacDonald et al. (2000), as the level above which effects on benthic biota are likely to be observed, demonstrating the potential toxicity of the accumulated sediments, especially in case of remobilization.

The reconstruction of $\mathrm{PAH}$ temporal trends therefore demonstrated significant $\mathrm{PAH}$ contamination but did not provide information on the sources responsible for these contaminations. To achieve this, it was necessary to study the distribution of isomers over time (Yunker et al., 2002).

\subsubsection{Distribution of PAH molar weights and isomers throughout the cores}

The abundances of 2-ring PAHs (mass 128; Na) were $<1 \%$ and those of 3-ring PAHs (masses 152,154, 166, and 178) were between $11-23 \%$ and $10-18 \%$ of the total PAHs for MAR16-02 and DAM17-02, respectively. Pn and An (mass 178) were the main components of this fraction, representing on average between $11.1 \%$ and $12.4 \%$ of the total PAHs. 4-ring PAHs (masses 202 and 228) were mostly represented with abundances between 34-51\% (MAR16-02) and 36-46\% (DAM17-02). The abundances of the 5-ring PAHs (masses 252 and 278) were between 24-42\% (MAR16-02) and 25-30\% (DAM17-02). The abundances of 6-ring PAHs (mass 276; IP and Bghi isomers) were between 7-15\% (MAR16-02) and 11$25 \%(\mathrm{DAM} 17-02)$.

This important contribution of 4-, 5-, and 6-ring PAHs has been observed in other French watersheds (e.g. Seine River watershed (Lorgeoux et al., 2016); Loire River watershed (Bertrand et al., 2015)) and is frequently observed in sediments downstream or adjacent to industrialized and/or urbanized areas (Yunker et al., 2002). Isomers with masses of 202, 228, 
252, and 276 are the major components of gasoline and diesel soot, as well as coal combustion emissions, of which the 202- and 252-mass isomers are predominant (Wang et al., 1999; Yunker et al., 2002). Low molecular weight (LMW) PAHs (2-3-rings) are more abundant in petrogenic products and low- to moderate-temperature combustion processes (e.g. biomass and coal burning in homes), whereas high molecular weight (HMW) PAHs (5-6rings) are products of high-temperature combustion of coal or petroleum from large power plants and factories or vehicular emissions (Ding et al., 2014). Thus, sediments of the lower reaches of the Eure River exhibited an anthropogenic pyrogenic PAH signature (Yunker et al., 2002), which can partly explain the strong correlation between PAHs and refractory $\mathrm{C}_{\text {org }}$ in the sediments. Indeed, soot is mainly composed of refractory $\mathrm{C}_{\text {org }}$ (Poot et al., 2014) and the strong link between PAHs and RC/TOC could confirm a predominant atmospheric input of PAHs (especially heavy PAHs) through soot from combustion processes. Nevertheless, this hypothesis must be further confirmed, as the link between PAHs and refractory $\mathrm{C}_{\text {org }}$ could occur during transport or deposition of the latter on the watershed soils.

In addition to discriminating between pyrogenic and petrogenic sources, diagnostic PAH ratios can be used to distinguish combustion sources (e.g. petroleum, coal, or wood combustion) (Yunker et al., 2002). Therefore, different diagnostic ratios based on the ratios of light and heavy PAHs were calculated (Fig. 5). The Fl and Py isomers were the first and third most abundant isomers for MAR16-02 (Fl: 14.5\%; Py: 12.1\%) and DAM17-02 (Fl: 16.6\%; Py: 13.6\%), respectively. All $\mathrm{Fl} /(\mathrm{Fl}+\mathrm{Py})$ ratios exceeded $0.5\left(\mathrm{Fl} /(\mathrm{Fl}+\mathrm{Py})_{\text {mean }}=0.54 \pm 0.01\right.$ for MAR16-02 and $\mathrm{Fl} /(\mathrm{Fl}+\mathrm{Py})_{\text {mean }}=0.55 \pm 0.01$ for DAM17-02), which is suggestive of a strong preponderance of coal and/or wood combustion as the main sources of PAH contamination (Budzinski et al., 1997; Yunker et al., 2002), as in the Seine River watershed (Lorgeoux et al., 2016). Moreover, the $\mathrm{BaA}$ and $\mathrm{Ch}$ isomers were among the most abundant for MAR16-02 (BaA: 8.8\%; Ch: 8.4\%) and DAM17-02 (BaA: 6.4\%; Ch: 6.5\%). The calculated BaA/228 
$(\mathrm{BaA} /(\mathrm{BaA}+\mathrm{Ch}) \mathrm{vs} \mathrm{Fl} /(\mathrm{Fl}+\mathrm{Py}))$ ratios were all greater than $0.45\left(\mathrm{BaA} / 228_{\text {mean }}=0.51 \pm 0.02\right.$ for MAR16-02; $\mathrm{BaA} / 228_{\text {mean }}=0.50 \pm 0.05$ for DAM17-02), which also suggests that the PAHs stored in the ponds of the lower reaches of the Eure River had pyrogenic rather than petrogenic source signatures (Fig. 5A) (Yunker et al., 2002). However, no logic was established in terms of temporality because the set of calculated ratios was limited to a restricted domain with little variability.

The average ratios obtained from the isomers of mass 276 (IP/(IP+Bghi) vs $\mathrm{Fl} /(\mathrm{Fl}+\mathrm{Py})$ ) were greater than $0.5\left(\mathrm{IP} /(\mathrm{IP}+\mathrm{Bghi})_{\text {mean }}=0.53 \pm 0.02\right.$ for $\mathrm{MAR} 16-02 ; \mathrm{IP} /(\mathrm{IP}+\mathrm{Bghi})_{\text {mean }}=0.53 \pm$ 0.04 for DAM17-02) but some values were below 0.5 (Fig. 5B). Fig. 5B shows that a temporal trend could be identified: the IP/(IP+Bghi) ratio was below 0.5 the mid-1980s for MAR16-02 and DAM17-02, due to an increase in the contribution of isomers with a mass of 276. This indicates that sources linked to petroleum combustion intensified from the late 1980s onwards; however, the $\mathrm{BaA} / 228$ ratio (Fig. 5A) was not descriptive of this temporal evolution. $\mathrm{BaA}(\mathrm{MW}=228)$ and $\mathrm{BaP}(\mathrm{MW}=278)$ have been shown to be more sensitive to photodegradation than most other PAHs (except An) when emitted to the atmosphere (Yunker et al., 2002). Therefore, given that isomers with masses of 276 and 202 are more stable than those with masses of 278 and 228, their use in diagnostic ratios allows for a better differentiation between combustion sources without significant artefacts related to their subsequent transformations.

The An/178 (An/(An+Pn) vs Fl/(Fl+Py)) ratios obtained for the two sediment records were greater than 0.1 (Fig. 5C). A ratio of 0.1 indicates a very small proportion of An relative to Pn. This is likely associated with substantial An photodegradation (i.e. given that An is much less stable than Pn) from the combustion source to its final deposition via atmospheric transport. On the other hand, the greater the distance from the combustion source to the deposition zone, the more the ratio tends towards 0.1 (Yunker et al., 2002). However, in 
contrast to previously studied ratios, the An/178 ratio averages are significantly different within the two sediment records $\left(\mathrm{An} / 178_{\text {mean }}=0.41 \pm 0.09\right.$ for MAR16-02; An $/ 178_{\text {mean }}=0.25$ \pm 0.04 for DAM17-02) and their temporal trends were also distinct. In the case of the DAM17-02 core, the ratio generally tended towards 0.10 from the 1940 s to the present day, i.e. towards a source corresponding mainly to combustion. This was also true for the MAR1602 core after the 1990s. However, the An/178 ratio for the MAR16-02 core exhibited high values (> 0.4) over the mid-1960s-1990s due to an increase in An concentrations throughout this period. Within the Seine River watershed, an enrichment in An in sediments was also recorded from 1971 onwards, without its origin being determined (Lorgeoux et al., 2016). It would appear that for the sediments of the Martot Pond, this increase started a few years earlier and stopped around the 1990s. Nonetheless, these inputs may share the same origin, which could be attributed to oil discharges in an aquatic system that did not undergo combustion. As the transport of PAHs was not carried out through the atmosphere, An was not affected by photodegradation and its concentration thus remained close to that of Pn (Tobiszewski and Namieśnik, 2012). As mentioned previously, Martot Pond was likely impacted by the contributions of the Seine estuary during tidal flows, which is not the case for Les Damps Pond, located upstream. However, Martot Pond is close to the industrial areas of Rouen, which were marked by strong petrochemical activity and significant river transport of oil between the 1960s and 1990s. It appears that after the 1990s, oil leaks during transport greatly decreased, leaving combustion processes as the only sources of sediment contamination.

\subsection{PCBs in sediments cores}

\subsubsection{General PCB trends in sediment cores}


Total PCB concentrations were recorded for the MAR16-02 and DAM17-02 cores (Fig. 6).

401 PCBs were not detected in the Seine Unit $(78-90 \mathrm{~cm})$ of MAR16-02 core. In contrast, the

402

403

404

405

406

407

408

409

410

411

412

413

414

415

Eure Unit of MAR16-02 and DAM17-02 exhibited concentrations ranging between 0.02-1.57 $\mathrm{mg} \mathrm{kg}^{-1}\left(\mathrm{PCB}_{\text {mean }}=0.72 \pm 0.05 \mathrm{mg} \mathrm{kg}^{-1}\right)$ and $0.09-1.60 \mathrm{mg} \mathrm{kg}^{-1}\left(\mathrm{PCB}_{\text {mean }}=0.50 \pm 0.06 \mathrm{mg}\right.$ $\mathrm{kg}^{-1}$ ). For MAR16-02, PCBs levels increased at the transition between the two sedimentary facies and reached a peak of $1.57 \pm 0.06 \mathrm{mg} \mathrm{kg}^{-1}$ in the late $1950 \mathrm{~s}$, whereas a $1.60 \pm 0.12 \mathrm{mg}$ $\mathrm{kg}^{-1}$ peak was recorded in DAM17-02 in the late 1960s. A general downward trend in PCB levels was then visible up to the surface of the sediment deposits. For MAR16-02, two concentration peaks were observed despite the downward trend, the first around 1976 (PCB = $0.68 \pm 0.13 \mathrm{mg} \mathrm{kg}^{-1}$ ) and the second in 1992-1996 with an extremely high concentration that reached $16.8 \mathrm{mg} \mathrm{kg}^{-1}$. For the most recent sediment deposits (from the 2000s onward), concentrations are relatively close or equal to $0.12 \pm 0.01 \mathrm{mg} \mathrm{kg}^{-1}$ and $0.18 \pm 0.05 \mathrm{mg} \mathrm{kg}^{-1}$ for MAR16-02 and DAM17-02, respectively.

The general temporal trend of PCB contents was similar to previously reported trends in France (Seine River watershed: Lorgeoux et al., 2016; Rhône River watershed: Desmet et al., 2012), Europe (UK: Sanders et al., 1992; Germany: Bruckmeier et al., 1997; Italy: Combi et al., 2020), and the US (Christensen and Lo, 1986; Van Metre et al., 1997), and were similar to temporal trends in global PCB production and consumption (Breivik et al., 2002). The maxima obtained during the 1950s-1970s $\left(\sim 1.6 \mathrm{mg} \mathrm{kg}^{-1}\right.$ for the two ponds) were higher than those historically recorded in several French watersheds, such as the Loire $\left(1.2 \mathrm{mg} \mathrm{kg}^{-1}\right.$, Dendievel et al., 2019), Garonne (0.145 mg kg-1 , Dendievel et al., 2019) and Rhône rivers watersheds (0.28 $\mathrm{mg} \mathrm{kg}^{-1}$, Desmet et al., 2012; $0.42 \mathrm{mg} \mathrm{kg}^{-1}$, Mourier et al., 2014); European watersheds such as the Brno Reservoir, Czech Republic (0.08 mg kg${ }^{-1}$, Franců et al., 2010); the Esthwaite Water, England (0.05 $\mathrm{mg} \mathrm{kg}^{-1}$, Sanders et al., 1992); or the Chattahoochee River watershed, US (0.38 $\mathrm{mg} \mathrm{kg}^{-1}$, Van Metre et al., 1997). It should be noted that total PCB 
concentrations were calculated from 7 congeners in the cited studies and up to 22 for Sanders et al. (1992), compared with the 6 congeners studied herein. Nevertheless, the maximum concentrations recorded in the Eure River watershed remain lower than those recorded in recent flood deposits in the Rhône River (Dendievel et al., 2019), the Seine River (2.31 mg $\mathrm{kg}^{-1}$, Lorgeoux et al., 2016), or the Seine estuary, France (5 mg kg${ }^{-1}$; Dendievel et al., 2019), the Lippe River, Germany (2.63 $\mathrm{mg} \mathrm{kg}^{-1}$, Heim et al., 2004), or Milwaukee Harbour, US (13.4 $\mathrm{mg} \mathrm{kg}^{-1}$, Christensen and Lo, 1986).

The detection of PCBs prior to 1955 (i.e. the year in which PCB production and consumption in France began to increase; Lorgeoux et al., 2016) may be consistent with the fact that PCB production in France began approximately in the 1930s (de Voogt and Brinkman, 1989). However, the maximum consumption recorded in France in 1975 does not correspond to the maximum concentrations in sediments recorded a few years earlier. The year 1975 also corresponds to the first bans on the use of PCBs in open systems (e.g. plasticizers, carbonless copy paper, lubricants, inks, laminating and impregnating agents, paints, adhesives, waxes, cement and plaster additives, casting and dedusting agents, sealing liquids, fire retardants, immersion oils, and pesticides (de Voogt and Brinkman, 1989; Bigus et al., 2014)), which may explain why it was after this date that the levels started to show a substantial decrease, especially in Martot Pond. Additionally, PCB concentrations began to stabilise to low levels in the early 1990s (with the exception of the 1992-1996 period in Martot Pond), which can be linked to the cessation of PCB production in France in 1984 (de Voogt and Brinkman, 1989) coupled with the ban on PCB use in France in 1987, including in closed-system applications (e.g. cooling liquids in transformers, dielectric liquids in large and small capacitors, heat-conducting fluids in heat-exchangers and fire- or heat-resistant corrosion-free hydraulic fluids in mining equipment and vacuum pumps (de Voogt and Brinkman, 1989; Kannan et al., 1992; Bigus et al., 2014)). In addition, some PCB 
concentrations recorded during the 1950s-1960s exceeded the probable effect concentrations (PECs; equal to $0.676 \mathrm{mg} \mathrm{kg}^{-1}$ for total PCBs) defined by MacDonald et al. (2000), as the level above which effects on benthic biota are likely to be observed, demonstrating the potential toxicity of the accumulated sediments, especially in case of remobilization.

Thus, the temporal reconstruction of PCB levels demonstrated a significant PCB contamination within the Eure River watershed, but only an analysis of the distribution of the congeners can allow for the determination of the contaminant sources.

\subsubsection{Distribution of PCB congeners}

Congener distributions were recorded for the MAR16-02 and DAM17-02 cores (Fig. 6). For the Eure Unit of MAR16-02 core, PCB180 was, on average, predominantly represented (23.1\%), followed by PCB138 (22.1\%), PCB153 (20.2\%), PCB101 (15.0\%), PCB52 (11.3\%), and PCB28 (8.2\%). Therefore, 6-chlorine PCBs (PCB138 + PCB153) were predominantly represented (42.3\%). For DAM17-02, PCB138 represented on average $42.8 \%$ of the $\sum$ PCBs, which combined with PCB153 (8.1\%) amounted to a 50.9\% representation of 6-Chlorine PCBs, whereas PCB101 represented on average 20.7\%, followed by PCB180 (18.8\%), PCB52 (5.9\%), and PCB28 (3.7\%). PCB28, the globally least represented congener, was detected beginning in the early 1950s, and its contribution has generally followed the trends shown by PCB concentrations. However, during the peak of PCB levels in the late 1950s for MAR16-02 and the 1960s for DAM17-02, PCB28 was the most represented congener $(25.4 \%$ and $26.5 \%$ respectively). From the late 1970s onwards, PCB28 represented less than $10 \%$ of $\sum$ PCBs for MAR16-02, whereas it was almost no longer detected in DAM17-02. PCB52, the second least represented congener, was detected from the beginning of the sediment records and, similar to PCB28, followed the overall global PCB trends. However, PCB52 was the second most represented congener during the 1950s peak concentration (21.7\%) for MAR16- 
02 and the third $(21.9 \%)$ during the 1960s peak for DAM17-02. The contribution of this isomer decreased overall afterwards $(<10 \%)$. PCB101 and PCB153 followed similar trends for MAR16-02, with a strong representation at the Eure/Seine unit transition (>30\%) and then decreased as the PCB concentration increased. Following the peak PCB concentration, the contribution of PCB101 decreased, although its contribution was approximately 20\%, whereas the contribution of PCB153 also stabilised at approximately 20\%. PCB138 also showed strong contributions from the Eure/Seine unit transition of the MAR16-02 core, which also decreased as the PCB concentration increased. Afterwards, the contribution of PCB138 increased overall towards the surface as the PCB concentrations decreased. The distribution of PCB101 was also important at the beginning of the DAM17-02 core (>40\%). For the MAR16-02 core, this congener decreased as PCB concentrations increased. In contrast to MAR16-02, the contribution of PCB153 was low for DAM17-02 and showed an increasing trend until the early 1980s $(\sim 17 \%)$. The contribution of PCB138 showed a broadly similar behaviour to that of PCB153 and reached nearly $70 \%$ at the end of the 1980s. Finally, PCB180 was only detected from the mid-1950s for MAR16-02 but its contribution increased over time and was very significant from the late 1990s onwards. Conversely, PCB180 showed a strong contribution at the beginning of the DAM17-02 record, which decreased with increasing PCB concentration.

Releases of PCBs to the environment can result from inputs to watercourses through leakage from facilities or discharges from landfills, as well as leaching from industrial or urban surfaces, but also from atmospheric deposition, in which case PCBs are mostly transported in particulate form (Zhou et al., 2001; Yang et al., 2012). More generally, industrial activities and urbanization are the primary causes of sediment PCB pollution (Bigus et al., 2014). France was one of the first countries to produce PCBs and is estimated to have contributed approximately $10 \%$ of the global production from 1930 to 1984 (i.e. $134,654 \mathrm{t}$ of the $1.5 \mathrm{Mt}$ 
500

501

502

503

504

505

506

507

508

509

510

511

512

513

514

produced globally) (de Voogt and Brinkman, 1989; Breivik et al., 2002). PCBs in France were produced under the names "Phenoclor" and "Pyralene". Moreover, it can be assumed that the "PCB technical mixture" used in France prior to 1987 was predominantly produced in France, regardless of its form and use.

Comparing PCB isomers (and thus comparing PCBs according to their chlorination degree) can be useful to identify the sources responsible for PCB releases to the environment and to assess changes in their use within a given watershed (Franců et al., 2010; Cai et al., 2016). Ratios of PCB28/PCB153 and PCB(28+53)/PCB(138+153+180) congeners were found to be below 1 for most of the MAR16-02 (mean $=0.43$ and 0.36, respectively) and DAM17-02 (mean $=0.61$ and 0.17 , respectively) cores (Fig. 7), confirming a dominance of "high chlorinated congeners" that are generally present in the composition of hydraulic fluids or thermostable lubricants, whereas "lower chlorinated mixtures" are used for less viscous applications (Franců et al., 2010). However, these ratios were greater than 1 during the highconcentration instances recorded in the late 1950s (Martot Pond) and 1960s (Les Damps Pond), confirming the dominance of "low chlorinated congeners" during these periods (Fig. 7). This could be explained by a contribution from at least two distinct sources during certain periods of high PCB use. If the production and use of formulations containing highly chlorinated PCBs were staggered over the period spanning from the 1930s to the late 1980s, the temporary dominance of low chlorinated congeners (tri- $\mathrm{Cl}$ and tetra- $\mathrm{Cl}$ ) may indicate the use and subsequent release of specific technical PCB mixtures, such as DP-3 or DP-4 (i.e. two types of Phenoclor mixtures). These technical mixtures are equivalent to the Aroclor 1016 and 1242 mixtures (Kannan et al., 1992; Breivik et al., 2002), which are mainly composed PCBs containing 2-5 chlorines (Frame, 1997; Breivik et al., 2002). These observations are consistent with the reports of Franců et al. (2010) (Brno Reservoir, Czech Republic), whereby the temporary dominance of lower chlorinated congeners corresponded to (accidental) input 
from a former transformer and capacitor manufacturing plant that used a low chlorinated technical PCB mixture called Delor 103 (equivalent to Aroclor 1242, which is produced in the US). As previously reported by Cai et al. (2016) and Yang et al. (2012), the predominance of heavy congeners could correspond to atmospheric inputs over long distances. However, this occurred in countries that were not direct producers of PCBs at the time of deposition. Other authors indicate that the presence of lighter PCBs is more suggestive of substantial atmospheric contribution, given that these congeners are more susceptible to long-range transport as they are less prone to photodegradation than highly chlorinated PCBs. Therefore, the predominance of heavier PCBs seems to suggest a larger contribution of emissions from local sources (Alegria et al., 2016). Halfadji et al. (2019) noted that sites contaminated with highly chlorinated PCBs were near petrochemical industrial zones, which is also the case for Martot Pond.

It should be noted that during the pollution peak recorded in Martot Pond during the 19921996 period, the previously calculated ratios remained below 1, demonstrating the occurrence of a pollution source that was distinct from that responsible for the heavy contamination a few decades earlier. Given that the studied area was not impacted by major leaks associated with the degradation of electrical installations, this sudden increase in contamination level could be attributed to a very localised wild discharge. Notably, Les Damps Pond (located upstream) did not show this intense pollution peak and the pollution date occurred very shortly after the ban on the use of PCBs in France. Unfortunately, some industrial discharges continued even after 1987, as was the case in the Rhone River watershed, where high PCB concentrations were recorded several years after cessation of their use (Desmet et al., 2012).

\section{Conclusions}


This study demonstrated that PAHs, particularly heavy PAHs, had a high affinity for

551

552

553

554

555

556

557

558

559

560

561

562

563 refractory $\mathrm{C}_{\text {org }}$, whereas PCBs showed a lower affinity. The Eure River watershed has been subject to significant POP contaminations since the 1940s, corresponding to the same order of magnitude as that recorded in other French or European watersheds. The abundance of different PAH isomers and their diagnostic ratios demonstrated that the high concentrations of PAHs recorded during the 1940s-1960s were of pyrogenic origin (i.e. derived from combustion processes), whereas certain signatures recorded in more recent deposits (up to the 1990s) exhibited an evolution towards a petrogenic origin. Furthermore, PCB temporal trends, particularly their high concentrations during the 1950s-1970s, are generally linked to the production, consumption, and bans on the use of PCBs in France. The distribution of PCB congeners and certain congener ratios demonstrated that the high releases during the 1950s1970s were likely linked to the release of "technical mixtures PCBs" composed of "low chlorinated congeners" into the river, whereas the most recent inputs were mainly attributed to atmospheric inputs of "high chlorinated congeners", with the exception of a local high undefined contamination recorded in Martot Pond.

\section{Acknowledgements}

This work is part of the OSS 276 project, financially supported by the Seine-Normandie Water Agency (France). This work is support by the CNRS toward EC2CO grant (AvantSeine project). Gardes Th. grant was funded by the Region Normandie, which supports the scientific consortium SCALE UMR CNRS 3730. CNRS also supports the French national cyber-Repository (https://www.cybercarotheque.fr/) which is a portal for metadata associated with marine, lake/river sediment cores stored in French laboratories. This project was initiated by CLIMCOR project (http://climcor-equipex.dt.insu.cnrs.fr/). 
Our paper is a contribution to ROZA-LTER-fr project : Retro-Observatory of sedimentary

Archive from French LTER (http://ccwbvps18.in2p3.fr/maps/visualiseur-coyoxhup\#project)

which is a portal for data associated with marine, lake sediment cores stored in LTER French

laboratories.

\section{References}

Ab Razak, I.A., Li, A., Christensen, E.R., 1996. Association of PAHs, PCBs, 137Cs, and 210Pb with clay, silt, and organic carbon in sediments. Water Science and Technology, Water Quality International '96 Part 4 34, 29-35. https://doi.org/10.1016/S0273-1223(96)00719-6

Abarnou, A., Avoine, J., Dupont, J.P., Lafite, R., Simon, S., 1987. Role of suspended sediments on the distribution of PCB in the Seine Estuary (France). Continental Shelf Research, Dynamics of Turbid Coastal Environments 7, 1345-1350. https://doi.org/10.1016/0278-4343(87)90038-0

Ahad, J.M.E., Jautzy, J.J., Cumming, B.F., Das, B., Laird, K.R., Sanei, H., 2015. Sources of polycyclic aromatic hydrocarbons (PAHs) to northwestern Saskatchewan lakes east of the Athabasca oil sands. Organic Geochemistry 80, 35-45. https://doi.org/10.1016/j.orggeochem.2015.01.001

Alegria, H., Martinez-Colon, M., Birgul, A., Brooks, G., Hanson, L., Kurt-Karakus, P., 2016. Historical sediment record and levels of PCBs in sediments and mangroves of Jobos Bay, Puerto Rico. Science of The Total Environment 573, 1003-1009. https://doi.org/10.1016/j.scitotenv.2016.08.165

Bertrand, O., Mondamert, L., Grosbois, C., Dhivert, E., Bourrain, X., Labanowski, J., Desmet, M., 2015. Storage and source of polycyclic aromatic hydrocarbons in sediments downstream of a major coal district in France. Environmental Pollution 207, 329-340. https://doi.org/10.1016/j.envpol.2015.09.028

Bigus, P., Tobiszewski, M., Namieśnik, J., 2014. Historical records of organic pollutants in sediment cores. Marine Pollution Bulletin 78, 26-42. https://doi.org/10.1016/j.marpolbul.2013.11.008

Blanchard, M., Teil, M.-J., Guigon-Moreau, E., Larcher-Tiphagne, K., Ollivon, D., Garban, B., Chevreuil, M., 2007. Persistent toxic substance inputs to the river Seine basin (France) via atmospheric deposition and urban sludge application. The Science of the Total Environment 375.

Breivik, K., Sweetman, A., Pacyna, J.M., Jones, K.C., 2002. Towards a global historical emission inventory for selected PCB congeners - a mass balance approach: 1. Global production and consumption. Science of The Total Environment 290, 181-198. https://doi.org/10.1016/S0048-9697(01)01075-0

Bruckmeier, B.F.A., Jüttner, I., Schramm, K.-W., Winkler, R., Steinberg, C.E.W., Kettrup, A., 1997. PCBs and PCDD/Fs in lake sediments of Großer Arbersee, Bavarian Forest, South Germany. Environmental Pollution 95, 19-25. https://doi.org/10.1016/S0269-7491(96)00118-2

Budzinski, H., Jones, I., Bellocq, J., Piérard, C., Garrigues, P., 1997. Evaluation of sediment contamination by polycyclic aromatic hydrocarbons in the Gironde estuary. Marine Chemistry, 4th International Symposium on the Biogeochemistry of Model Estuaries 58, 8597. https://doi.org/10.1016/S0304-4203(97)00028-5

Burgess, R.M., Ryba, S.A., Cantwell, M.G., Gundersen, J.L., 2001. Exploratory Analysis of the Effects of Particulate Characteristics on the Variation in Partitioning of Nonpolar Organic Contaminants to Marine Sediments. Water Research 35, 4390-4404. https://doi.org/10.1016/S0043-1354(01)00179-8 
Cai, Y., Wang, X., Wu, Y., Li, Y., Ya, M., 2016. Over 100-year sedimentary record of polycyclic aromatic hydrocarbons (PAHs) and organochlorine compounds (OCs) in the continental shelf of the East China Sea. Environmental Pollution 219, 774-784. https://doi.org/10.1016/j.envpol.2016.07.053

Callender, E., 2000. Geochemical effects of rapid sedimentation in aquatic systems: minimal diagenesis and the preservation of historical metal signatures. Journal of Paleolimnology 23, 243-260. https://doi.org/10.1023/A:1008114630756

Carrie, J., Sanei, H., Stern, G., 2012. Standardisation of Rock-Eval pyrolysis for the analysis of recent $\begin{array}{llll}\text { sediments and } \quad \text { Organic } & \text { Geochemistry }\end{array}$ https://doi.org/10.1016/j.orggeochem.2012.01.011

Chevreuil, M., Blanchard, M., Teil, M.J., Chesterikoff, A., 1998. Polychlorobiphenyl behaviour in the water/sediment system of the Seine river, France. Water Research 32, 1204-1212. https://doi.org/10.1016/S0043-1354(97)00328-X

Chevreuil, M., Chesterikoff, A., Létolle, R., Granier, L., 1989. Atmospheric pollution and fallout by PCBS and organochlorine pesticides (Ile-De-France). Water Air Soil Pollut 43, 73-83. https://doi.org/10.1007/BF00175584

Chevreuil, M., Granier, L., 1991. Seasonal cycle of polychlorinated biphenyls in the waters of the catchment basin of the river seine (France). Water Air Soil Pollut 59, 217-229. https://doi.org/10.1007/BF00211831

Chevreuil, M., Granier, L., Chesterikoff, A., Létolle, R., 1990. Polychlorinated biphenyls partitioning in waters from river, filtration plant and wastewater plant: the case for paris (france). Water Research 24, 1325-1333. https://doi.org/10.1016/0043-1354(90)90149-Z

Christensen, E.R., Lo, C.-K., 1986. Polychlorinated biphenyls in dated sediments of Milwaukee Harbour, Wisconsin, USA. Environmental Pollution Series B, Chemical and Physical 12, 217 232. https://doi.org/10.1016/0143-148X(86)90011-X

Combi, T., Pintado-Herrera, M.G., Lara-Martín, P.A., Lopes-Rocha, M., Miserocchi, S., Langone, L., Guerra, R., 2020. Historical sedimentary deposition and flux of PAHs, PCBs and DDTs in sediment cores from the western Adriatic Sea. Chemosphere 241, 125029. https://doi.org/10.1016/j.chemosphere.2019.125029

Copard, Y., Di $\square$ Giovanni, C., Martaud, T., Albéric, P., Olivier, J.-E., 2006. Using Rock-Eval 6 pyrolysis for tracking fossil organic carbon in modern environments: implications for the roles of erosion and weathering. Earth Surface Processes and Landforms 31, 135-153. https://doi.org/10.1002/esp.1319

de Voogt, P., Brinkman, U., 1989. Production, properties and usage of polychlorinated biphenyls, in: Halogenated Biphenyls, Terphenyls, Naphtalenes, Dibenzodioxins and Related Products. Topics in Environmental Health. pp. 3-45.

Décret n87-59, 1987. Décret n87-59 du 2 février 1987 relatif à la mise sur le marché, à l'utilisation et à l'élimination des polychlorobiphényles et polychloroterphényles, 87-59.

Dendievel, A.-M., Mourier, B., Coynel, A., Evrard, O., Labadie, P., Ayrault, S., Debret, M., Koltalo, F., Copard, Y., Faivre, Q., Gardes, T., Vauclin, S., Budzinski, H., Grosbois, C., Winiarski, T., Desmet, M., 2019. Spatio-temporal assessment of the PCB sediment contamination in the four main French River Basins (1945\&ndash;2018). Earth System Science Data Discussions 1-23. https://doi.org/10.5194/essd-2019-167

Desmet, M., Mourier, B., Mahler, B.J., Van Metre, P.C., Roux, G., Persat, H., Lefèvre, I., Peretti, A., Chapron, E., Simonneau, A., Miège, C., Babut, M., 2012. Spatial and temporal trends in PCBs in sediment along the lower Rhône River, France. Science of The Total Environment 433, 189-197. https://doi.org/10.1016/j.scitotenv.2012.06.044

Ding, S., Xu, Y., Wang, Y., Zhang, X., Zhao, L., Ruan, J., Wu, W., 2014. Spatial and Temporal Variability of Polycyclic Aromatic Hydrocarbons in Sediments from Yellow River-Dominated Margin [WWW Document]. The Scientific World Journal. https://doi.org/10.1155/2014/654183

Douglas, G.S., Bence, A.E., Prince, R.C., McMillen, S.J., Butler, E.L., 1996. Environmental Stability of Selected Petroleum Hydrocarbon Source and Weathering Ratios. Environ. Sci. Technol. 30, 2332-2339. https://doi.org/10.1021/es950751e 
Duursma, E.K., Nieuwenhuize, J., van Liere, J.M., 1989. Polychlorinated biphenyl equilibria in an estuarine system. Science of The Total Environment 79, 141-155. https://doi.org/10.1016/0048-9697(89)90358-6

Fernandes, M.B., Sicre, M.-A., Boireau, A., Tronczynski, J., 1997. Polyaromatic hydrocarbon (PAH) distributions in the Seine River and its estuary. Marine Pollution Bulletin 34, 857-867. https://doi.org/10.1016/S0025-326X(97)00063-5

Fernandes, M.B., Sicre, M.-A., Broyelle, I., Lorre, A., Pont, D., 1999. Contamination by Polycyclic Aromatic Hydrocarbons (PAHs) in French and European rivers. Hydrobiologia 410, 343-348. https://doi.org/10.1023/A:1003751629504

Fernández, P., Vilanova, R.M., Grimalt, J.O., 1999. Sediment Fluxes of Polycyclic Aromatic Hydrocarbons in European High Altitude Mountain Lakes. Environ. Sci. Technol. 33, 37163722. https://doi.org/10.1021/es9904639

Frame, G.M., 1997. A collaborative study of 209 PCB congeners and 6 Aroclors on 20 different HRGC columns1. Retention and coelution database. Fresenius J Anal Chem 357, 701-713. https://doi.org/10.1007/s002160050237

Franců, E., Schwarzbauer, J., Lána, R., Nývlt, D., Nehyba, S., 2010. Historical Changes in Levels of Organic Pollutants in Sediment Cores from Brno Reservoir, Czech Republic. Water Air Soil Pollut 209, 81-91. https://doi.org/10.1007/s11270-009-0182-x

Gardes, T., Debret, M., Copard, Y., Coynel, A., Deloffre, J., Fournier, M., Revillon, S., Nizou, J., Develle, A.-L., Sabatier, P., Marcotte, S., Patault, E., Faivre, Q., Portet-Koltalo, F., 2020a. Flux estimation, temporal trends and source determination of trace metal contamination in a major tributary of the Seine estuary, France. Science of The Total Environment 138249. https://doi.org/10.1016/j.scitotenv.2020.138249

Gardes, T., Debret, M., Copard, Y., Patault, E., Winiarski, T., Develle, A.-L., Sabatier, P., Dendievel, A.-M., Mourier, B., Marcotte, S., Leroy, B., Portet-Koltalo, F., 2020b. Reconstruction of anthropogenic activities in legacy sediments from the Eure River, a major tributary of the Seine Estuary (France). CATENA 190, 104513. https://doi.org/10.1016/j.catena.2020.104513

Gasperi, J., Garnaud, S., Rocher, V., Moilleron, R., 2009. Priority pollutants in surface waters and settleable particles within a densely urbanised area: Case study of Paris (France). Science of The Total Environment 407.

Granier, L.K., Chevreuil, M., 1997. Behaviour and spatial and temporal variations of polychlorinated biphenyls and lindane in the urban atmosphere of the Paris area, France. Atmospheric Environment 31, 3787-3802. https://doi.org/10.1016/S1352-2310(97)00210-0

Gschwend, P.M., Wu, Shianchee., 1985. On the constancy of sediment-water partition coefficients of hydrophobic organic pollutants. Environ. Sci. Technol. 19, 90-96. https://doi.org/10.1021/es00131a011

Halfadji, A., Touabet, A., Portet-Koltalo, F., Derf, F.L., Merlet-Machour, N., 2019. Concentrations and Source Identification of Polycyclic Aromatic Hydrocarbons (PAHs) and Polychlorinated Biphenyls (PCBs) in Agricultural, Urban/Residential, and Industrial Soils, East of Oran (Northwest Algeria). Polycyclic Aromatic Compounds 39, 299-310. https://doi.org/10.1080/10406638.2017.1326947

Hatzinger, P.B., Alexander, Martin., 1995. Effect of Aging of Chemicals in Soil on Their Biodegradability and Extractability. Environ. Sci. Technol. 29, 537-545. https://doi.org/10.1021/es00002a033

Heemken, O.P., Stachel, B., Theobald, N., Wenclawiak, B.W., 2000. Temporal Variability of Organic Micropollutants in Suspended Particulate Matter of the River Elbe at Hamburg and the River Mulde at Dessau, Germany. Arch. Environ. Contam. Toxicol. 38, 11-31. https://doi.org/10.1007/s002449910003

Heim, S., Schwarzbauer, J., Kronimus, A., Littke, R., Woda, C., Mangini, A., 2004. Geochronology of anthropogenic pollutants in riparian wetland sediments of the Lippe River (Germany). Organic Geochemistry, Advances in Organic Geochemistry 2003. Proceedings of the 21st International Meeting on Organic Geochemistry 35, 1409-1425. https://doi.org/10.1016/j.orggeochem.2004.03.008

Kannan, N., Schulz-bull, D.E., Petrick, G., Duinker, J.C., 1992. High Resolution PCB Analysis of Kanechlor, Phenoclor and Sovol Mixtures Using Multidimensional Gas Chromatography. 
International Journal of Environmental

Analytical Chemistry

47, 201-215. https://doi.org/10.1080/03067319208027029

Karickhoff, S.W., Brown, D.S., Scott, T.A., 1979. Sorption of hydrophobic pollutants on natural sediments. Water Research 13, 241-248. https://doi.org/10.1016/0043-1354(79)90201-X

Lafargue, E., Marquis, F., Pillot, D., 1998. Rock-Eval 6 Applications in Hydrocarbon Exploration, Production, and Soil Contamination Studies. Revue de l'Institut Français du Pétrole 53, 421437. https://doi.org/10.2516/ogst:1998036

Le Cloarec, M.-F., Bonte, P.H., Lestel, L., Lefèvre, I., Ayrault, S., 2011. Sedimentary record of metal contamination in the Seine River during the last century. Physics and Chemistry of the Earth, Parts A/B/C, Man and River Systems: From pressures to physical, chemical and ecological status 36, 515-529. https://doi.org/10.1016/j.pce.2009.02.003

Lorgeoux, C., Moilleron, R., Gasperi, J., Ayrault, S., Bonté, P., Lefèvre, I., Tassin, B., 2016. Temporal trends of persistent organic pollutants in dated sediment cores: Chemical fingerprinting of the anthropogenic impacts in the Seine River basin, Paris. Science of The Total Environment 541, 1355-1363. https://doi.org/10.1016/j.scitotenv.2015.09.147

MacDonald, D.D., Ingersoll, C.G., Berger, T.A., 2000. Development and Evaluation of ConsensusBased Sediment Quality Guidelines for Freshwater Ecosystems. Arch. Environ. Contam. Toxicol. 39, 20-31. https://doi.org/10.1007/s002440010075

Marchand, M., 1989. Les PCB dans l'environnement marin. Aspects géochimiques d'apports et de distribution. Cas du littoral français. rseau 2, 373-403. https://doi.org/10.7202/705036ar

Means, J.C., Wood, S.G., Hassett, J.J., Banwart, W.L., 1980. Sorption of polynuclear aromatic hydrocarbons by sediments and soils. Environ. Sci. Technol. 14, 1524-1528. https://doi.org/10.1021/es60172a005

Meybeck, M., 2002. Riverine quality at the Anthropocene: Propositions for global space and time analysis, illustrated by the Seine River. Aquat. Sci. 64, 376-393. https://doi.org/10.1007/PL00012593

Mourier, B., Desmet, M., Van Metre, P.C., Mahler, B.J., Perrodin, Y., Roux, G., Bedell, J.-P., Lefèvre, I., Babut, M., 2014. Historical records, sources, and spatial trends of PCBs along the Rhône River (France). Sci. Total Environ. 476-477, 568-576. https://doi.org/10.1016/j.scitotenv.2014.01.026

Oliveira, César, Martins, N., Tavares, J., Pio, C., Cerqueira, M., Matos, M., Silva, H., Oliveira, Cristina, Camões, F., 2011. Size distribution of polycyclic aromatic hydrocarbons in a roadway tunnel in Lisbon, Portugal. Chemosphere 83, 1588-1596. https://doi.org/10.1016/j.chemosphere.2011.01.011

Ollivon, D., Garban, B., Blanchard, M., Teil, M.J., Carru, A.M., Chesterikoff, C., Chevreuil, M., 2002. Vertical Distribution and Fate of Trace Metals and Persistent Organic Pollutants in Sediments of the Seine and Marne Rivers (France). Water, Air, \& Soil Pollution 134, 57-79. https://doi.org/10.1023/A:1014194532128

Page, D.S., Boehm, P.D., Douglas, G.S., Bence, A.E., Burns, W.A., Mankiewicz, P.J., 1999. Pyrogenic Polycyclic Aromatic Hydrocarbons in Sediments Record Past Human Activity: A Case Study in Prince William Sound, Alaska. Marine Pollution Bulletin 38, 247-260. https://doi.org/10.1016/S0025-326X(98)00142-8

Piérard, C., Budzinski, H., Garrigues, P., 1996. Grain-Size Distribution of Polychlorobiphenyls in Coastal Sediments. Environ. Sci. Technol. 30, 2776-2783. https://doi.org/10.1021/es9600035

Poot, A., Jonker, M.T.O., Gillissen, F., Koelmans, A.A., 2014. Explaining PAH desorption from sediments using Rock Eval analysis. Environmental Pollution 193, 247-253. https://doi.org/10.1016/j.envpol.2014.06.041

Quémerais, B., Lemieux, C., Lum, K.R., 1994. Concentrations and sources of PCBs and organochlorine pesticides in the St. Lawrence River (Canada) and its tributaries. Chemosphere 29, 591-610. https://doi.org/10.1016/0045-6535(94)90446-4

Salvadó, J.A., Grimalt, J.O., López, J.F., Durrieu de Madron, X., Pasqual, C., Canals, M., 2013. Distribution of organochlorine compounds in superficial sediments from the Gulf of Lion, northwestern Mediterranean Sea. Progress in Oceanography, Integrated study of a deep submarine canyon and adjacent open slopes in the Western Mediterranean Sea: an essential habitat 118, 235-248. https://doi.org/10.1016/j.pocean.2013.07.014 
Sanders, G., Jones, K.C., Hamilton-Taylor, J., Doerr, H., 1992. Historical inputs of polychlorinated biphenyls and other organochlorines to a dated lacustrine sediment core in rural England. Environ. Sci. Technol. 26, 1815-1821. https://doi.org/10.1021/es00033a016

Shi, Z., Tao, S., Pan, B., Liu, W.X., Shen, W.R., 2007. Partitioning and source diagnostics of polycyclic aromatic hydrocarbons in rivers in Tianjin, China. Environmental Pollution, Lichens in a Changing Pollution Environment 146, 492-500. https://doi.org/10.1016/j.envpol.2006.07.009

Tobiszewski, M., Namieśnik, J., 2012. PAH diagnostic ratios for the identification of pollution $\begin{array}{lllll}\text { emission } & \text { sources. } & \text { Environmental } & \text { Pollution } & 162,\end{array}$ https://doi.org/10.1016/j.envpol.2011.10.025

Tsapakis, M., Stephanou, E.G., Karakassis, I., 2003. Evaluation of atmospheric transport as a nonpoint source of polycyclic aromatic hydrocarbons in marine sediments of the Eastern Mediterranean. Marine Chemistry 80, 283-298. https://doi.org/10.1016/S03044203(02)00132-9

US EPA, 2015. Toxic and Priority Pollutants Under the Clean Water Act [WWW Document]. URL https://www.epa.gov/eg/toxic-and-priority-pollutants-under-clean-water-act (accessed 10.17.19).

Van Metre, P.C., Callender, E., Fuller, C.C., 1997. Historical Trends in Organochlorine Compounds in River Basins Identified Using Sediment Cores from Reservoirs. Environ. Sci. Technol. 31, 2339-2344. https://doi.org/10.1021/es960943p

Van Metre, P.C., Mesnage, V., Laignel, B., Motelay, A., Deloffre, J., 2008. Origins of SedimentAssociated Contaminants to the Marais Vernier, the Seine Estuary, France. Water Air Soil Pollut 191, 331-344. https://doi.org/10.1007/s11270-008-9628-9

Wan, X., Pan, X., Wang, B., Zhao, S., Hu, P., Li, F., Boulanger, B., 2011. Distributions, historical trends, and source investigation of polychlorinated biphenyls in Dianchi Lake, China. Chemosphere 85, 361-367. https://doi.org/10.1016/j.chemosphere.2011.06.098

Wang, Z., Fingas, M., Shu, Y.Y., Sigouin, L., Landriault, M., Lambert, P., Turpin, R., Campagna, P., Mullin, J., 1999. Quantitative Characterization of PAHs in Burn Residue and Soot Samples and Differentiation of Pyrogenic PAHs from Petrogenic PAHs-The 1994 Mobile Burn Study. Environ. Sci. Technol. 33, 3100-3109. https://doi.org/10.1021/es990031y

Yang, H., Zhuo, S., Xue, B., Zhang, C., Liu, W., 2012. Distribution, historical trends and inventories of polychlorinated biphenyls in sediments from Yangtze River Estuary and adjacent East China Sea. Environmental Pollution, Interactions Between Indoor and Outdoor Air Pollution Trends and Scientific Challenges 169, 20-26. https://doi.org/10.1016/j.envpol.2012.05.003

Yunker, M.B., Macdonald, R.W., Vingarzan, R., Mitchell, R.H., Goyette, D., Sylvestre, S., 2002. PAHs in the Fraser River basin: a critical appraisal of PAH ratios as indicators of PAH source and composition. Organic Geochemistry 33, 489-515. https://doi.org/10.1016/S01466380(02)00002-5

Zennegg, M., Kohler, M., Hartmann, P.C., Sturm, M., Gujer, E., Schmid, P., Gerecke, A.C., Heeb, N.V., Kohler, H.-P.E., Giger, W., 2007. The historical record of PCB and PCDD/F deposition at Greifensee, a lake of the Swiss plateau, between 1848 and 1999. Chemosphere, Halogenated Persistent Organic Pollutants Dioxin 2004 67, 1754-1761. https://doi.org/10.1016/j.chemosphere.2006.05.115

Zhang, J., Cai, L., Yuan, D., Chen, M., 2004. Distribution and sources of polynuclear aromatic hydrocarbons in Mangrove surficial sediments of Deep Bay, China. Marine Pollution Bulletin 49, 479-486. https://doi.org/10.1016/j.marpolbul.2004.02.030

Zhou, J.L., Maskaoui, K., Qiu, Y.W., Hong, H.S., Wang, Z.D., 2001. Polychlorinated biphenyl congeners and organochlorine insecticides in the water column and sediments of Daya Bay, China. Environmental Pollution 113, 373-384. https://doi.org/10.1016/S0269-7491(00)001809 
Table 1. Sediment cores collected in Les Damps and Martot ponds (WGS 84).

\begin{tabular}{cccccc}
\hline \hline Pond & Core ID & IGSN & Longitude (X) & Latitude (Y) & Core Length (cm) \\
\hline \hline LES & DAM15-02 & IEM2C0016 & $1^{\circ} 10^{\prime} 9.05^{\prime \prime} \mathrm{E}$ & $49^{\circ} 18^{\prime} 16.13^{\prime \prime} \mathrm{N}$ & 80 \\
DAMPS & DAM17-02 & IEM2C000E & $1^{\circ} 10^{\prime} 13.26^{\prime \prime} \mathrm{E}$ & $49^{\circ} 18^{\prime} 15.66^{\prime \prime} \mathrm{N}$ & 90 \\
& MAR15-01 & IEM2C0001 & $1^{\circ} 03^{\prime} 1.68^{\prime \prime} \mathrm{E}$ & $49^{\circ} 17^{\prime} 49.68^{\prime \prime} \mathrm{N}$ & 138 \\
MARTOT & & & & \\
& MAR16-02 & IEM2C0008 & $1^{\circ} 03^{\prime} 2.60^{\prime \prime} \mathrm{E}$ & $49^{\circ} 17^{\prime} 49.30^{\prime \prime} \mathrm{N}$ & 129 \\
\hline \hline
\end{tabular}

Table 2. List of the analysed POPs.

\begin{tabular}{|c|c|c|c|c|c|}
\hline \multicolumn{3}{|l|}{ PAHs } & \multicolumn{3}{|c|}{ PCBs } \\
\hline Compounds & $\begin{array}{c}\text { Molar } \\
\text { weight } \\
\left(\mathrm{g} \mathrm{mol}^{-1}\right)\end{array}$ & X-Rings & Compounds & $\begin{array}{l}\text { Molar } \\
\text { weight } \\
\left(\mathrm{g} \mathrm{mol}^{-1}\right) \\
\end{array}$ & X-Chlorines \\
\hline Naphthalene (Na) & 128 & 2-Rings & PCB 28 & 258 & 3-Chlorine \\
\hline Acenaphthylene (Ayl) & 152 & ings & PCB 52 & 292 & 4-Chlorine \\
\hline Acenaphthene (Aen) & 154 & & PCB 101 & 326 & 5-Chlorine \\
\hline Fluorene $(\mathrm{F})$ & 166 & & $\begin{array}{l}\text { PCB } 138 \\
\text { PCB } 153\end{array}$ & $\begin{array}{l}361 \\
361\end{array}$ & $\begin{array}{l}\text { 6-Chlorine } \\
\text { 6-Chlorine }\end{array}$ \\
\hline $\begin{array}{l}\text { Phenanthrene (Pn) } \\
\text { Anthracene (An) }\end{array}$ & 178 & & PCB 180 & 395 & 7-Chlorine \\
\hline $\begin{array}{l}\text { Fluoranthene }(\mathrm{Fl}) \\
\text { Pyrene }(\mathrm{Py})\end{array}$ & 202 & 4-Rings & & & \\
\hline $\begin{array}{c}\text { Benz }[a] \text { anthracene }(\mathrm{BaA}) \\
\text { Chrysene }(\mathrm{Ch})\end{array}$ & 228 & & & & \\
\hline $\begin{array}{c}\text { Benzo }[b] \text { fluoranthene }(\mathrm{BbF}) \\
\text { Benzo }[k] \text { fluoranthene }(\mathrm{BkF}) \\
\text { Benzo }[a] \text { pyrene }(\mathrm{BaP})\end{array}$ & 252 & 5-Rings & & & \\
\hline Dibenz $[a, h]$ anthracene (DhA) & 278 & & & & \\
\hline $\begin{array}{c}\text { Indeno[1,2,3-cd]pyrene (IP) } \\
\text { Benzo[ghi]perylene (Bghi) } \\
\end{array}$ & 276 & 6-Rings & & & \\
\hline
\end{tabular}


Table 3. Comparison of maximum PCB concentrations in sediment cores of several watersheds.

\begin{tabular}{llll}
\hline \hline Location & $\begin{array}{l}\text { Concentration }\left(\mathrm{mg} \mathrm{kg}^{-}\right. \\
{ }^{1} \text { ) }\end{array}$ & Time interval & References \\
\hline \hline France & & & \\
\hline Eure River (lower section) & $1.57 / 1.60$ & $1950 \mathrm{~s}-1970 \mathrm{~s}$ & This study \\
Seine River (lower section) & 2.31 & 1960 & Lorgeoux et al., 2016 \\
Seine estuary & 5 & $1970 \mathrm{~s}$ & Dendievel et al., 2019 \\
Loire River (lower section) & 1.2 & $1973-1989$ & \\
& 1.4 & $2003-2008$ & \\
Garonne River (upper section) & 0.145 & 1998 & \\
Rhône River (lower section) & 2.4 (flood deposits) & $1995-1996$ & \\
& 0.42 & $1990-1995$ & Mourier et al., 2014 \\
Europe & 0.28 & 1991 & Desmet et al., 2012 \\
\hline Brno Reservoir (Czech Republic) & 0.08 & & \\
\hline Lippe River (Germany) & 2.63 & $1970 \mathrm{~s}-1980 \mathrm{~s}$ & Franců et al., 2010 \\
\hline Esthwaite Water (England) & 0.05 & $1980-1985$ & Heim et al., 2004 \\
\hline United States & & \multicolumn{2}{l}{ Sanders et al., 1992 } \\
\hline Lake Harding (Chattahoochee River) & 0.38 & $1950-1966$ & Van Metre et al., 1997 \\
\hline Milwaukee Harbour & 13.4 & $1970-1975$ & Christensen and Lo, \\
& & & 1986 \\
\hline
\end{tabular}



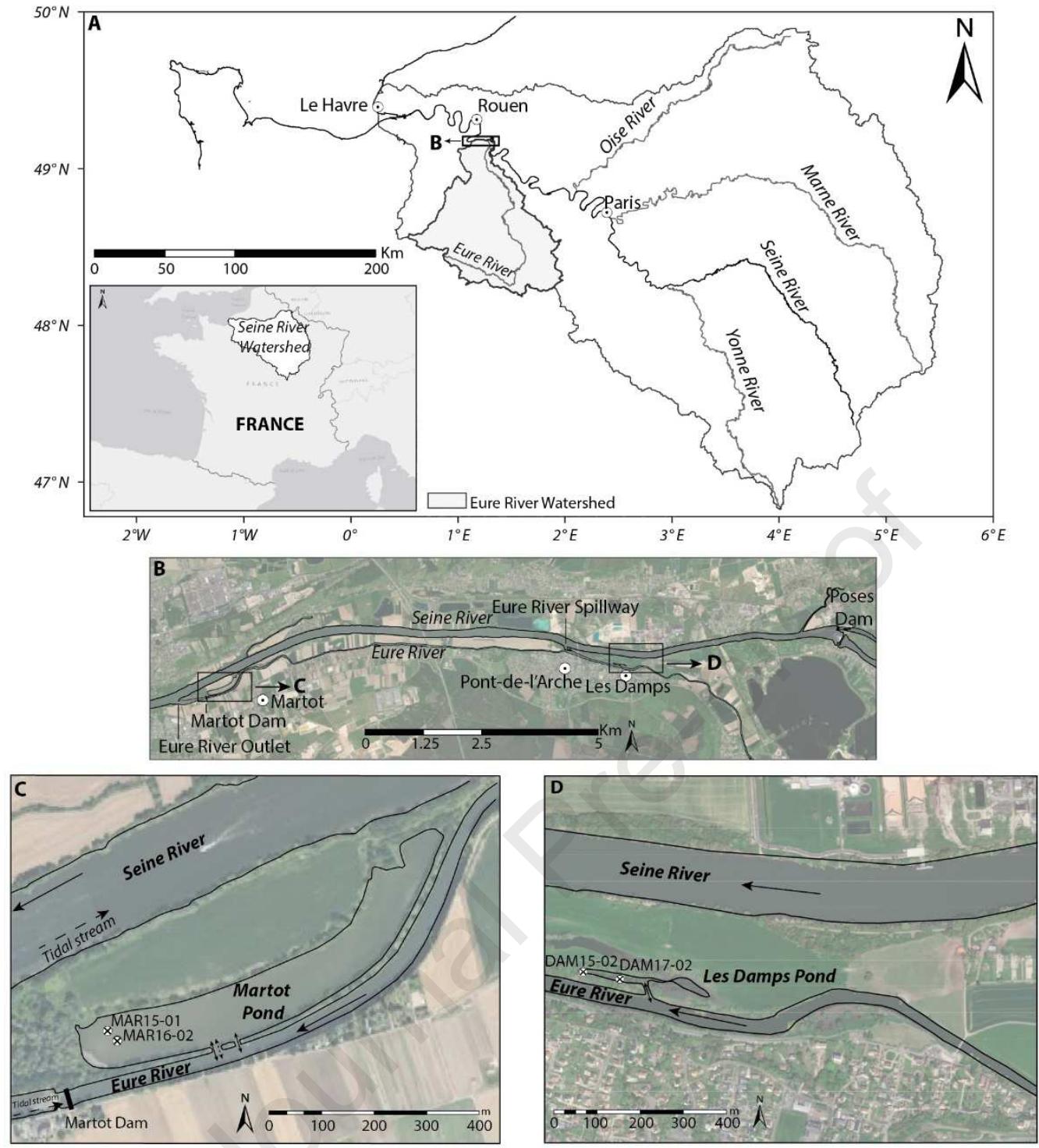

Figure 1. A. Seine River watershed; B. Study Area; C. Sediment core locations in Martot Pond and D. Sediment core locations in Les Damps Pond. 

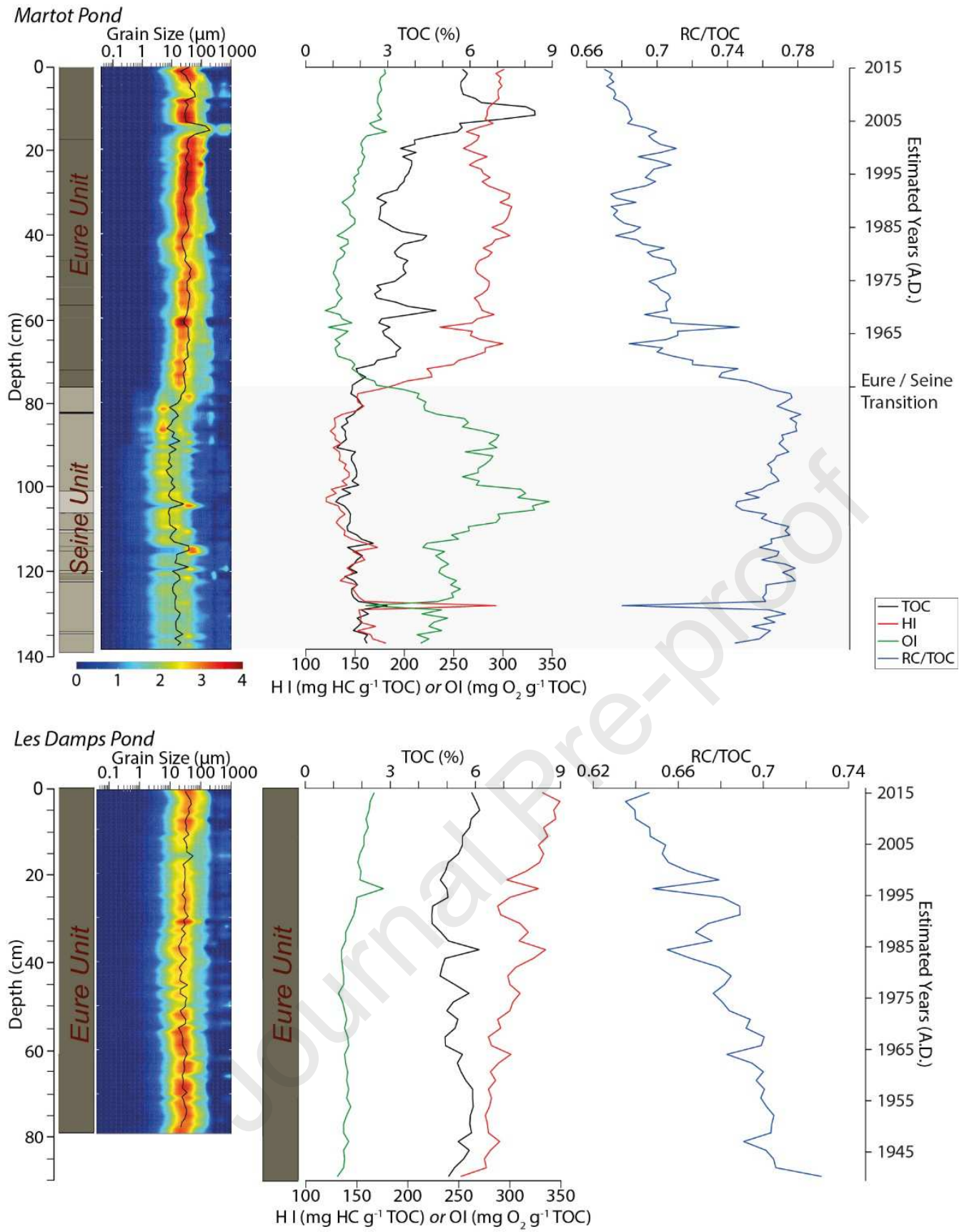

Figure 2. Grain size distribution, $\mathrm{D}_{50}$, TOC, HI, OI, and RC/TOC for the MAR15-01 core (Martot Pond) and for the DAM15-02 and DAM17-02 cores (Les Damps Pond). 
A

\section{Martot Pond}

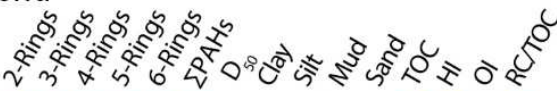

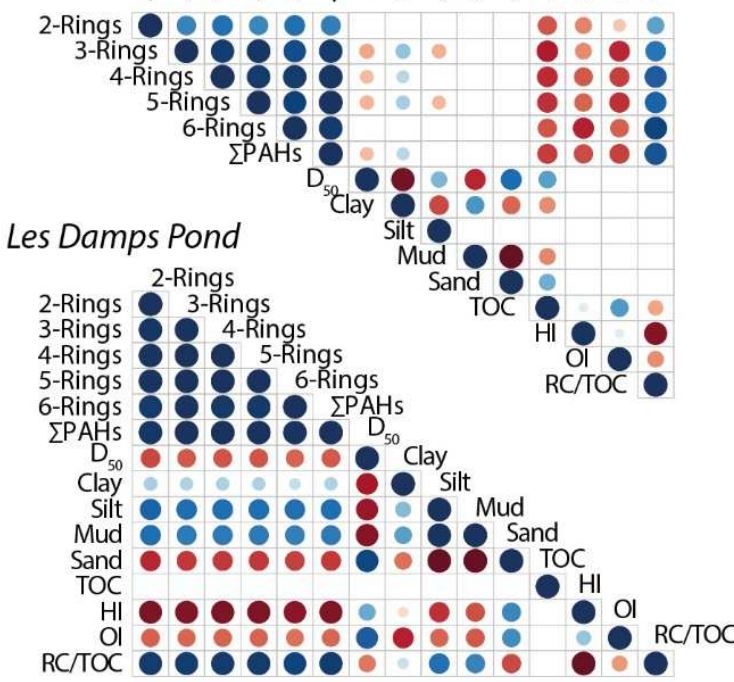

Martot Pond

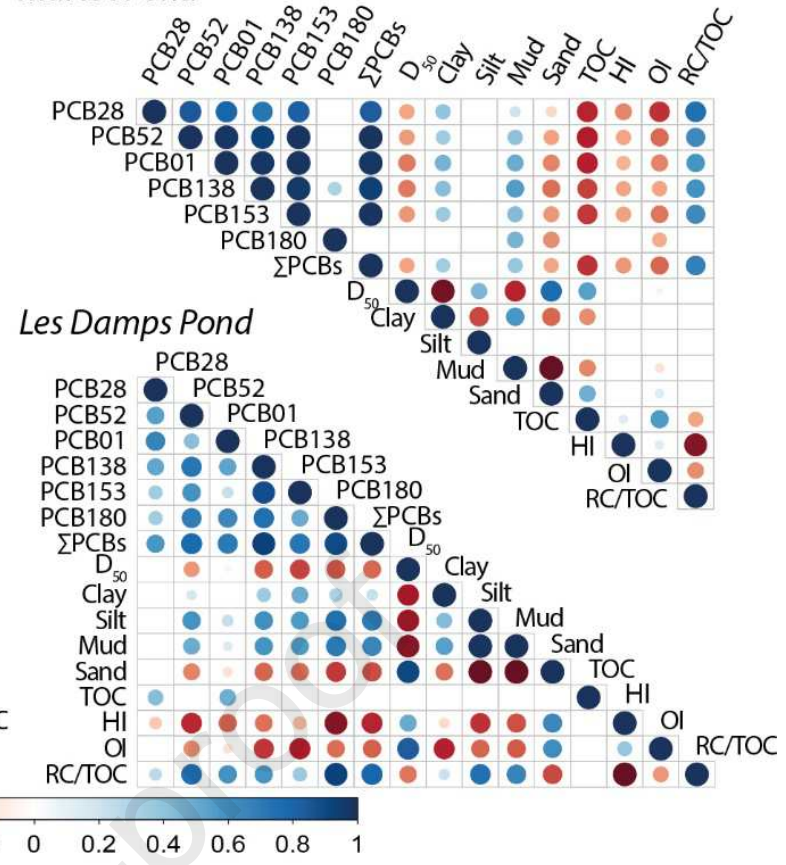

$\begin{array}{lllllllllll}-1 & -0.8 & -0.6 & -0.4 & -0.2 & 0 & 0.2 & 0.4 & 0.6 & 0.8 & 1\end{array}$
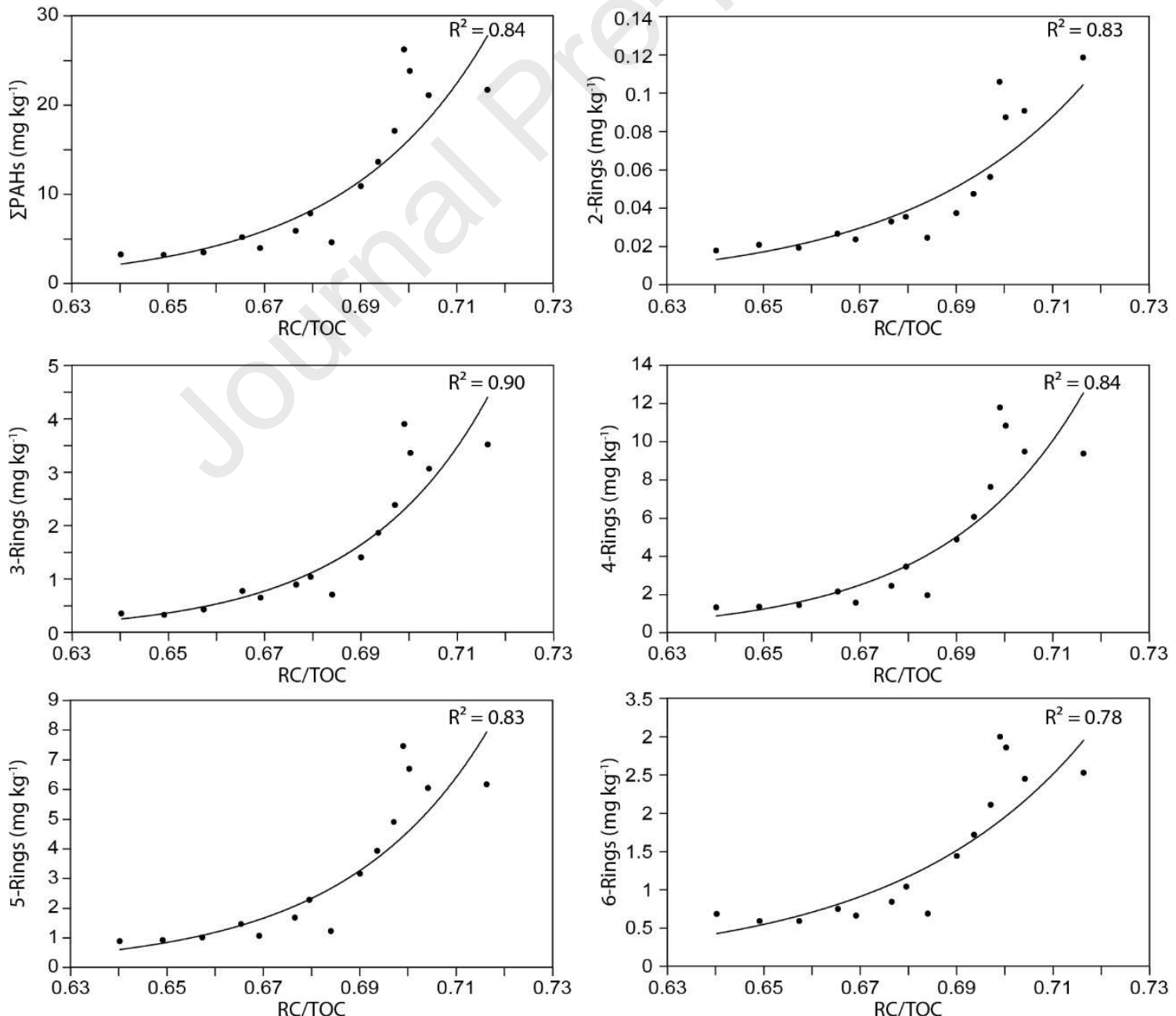

Figure 3. A. Correlation matrix of PAHs/PCBs and sediment characteristics for Martot and Les Damps ponds (Spearman correlation, $\mathrm{p}<0.05$ for all circles presented); B. $\sum \mathrm{PAHs}$, 2-3-Rings, 4-Rings, 5-Rings, and 6-Rings ( $\left.\mathrm{mg} \mathrm{kg}^{-1}\right)$ versus $\mathrm{RC} / \mathrm{TOC}$ for Les Damps Pond (from the correlation matrix). 


\section{Journal Pre-proof}
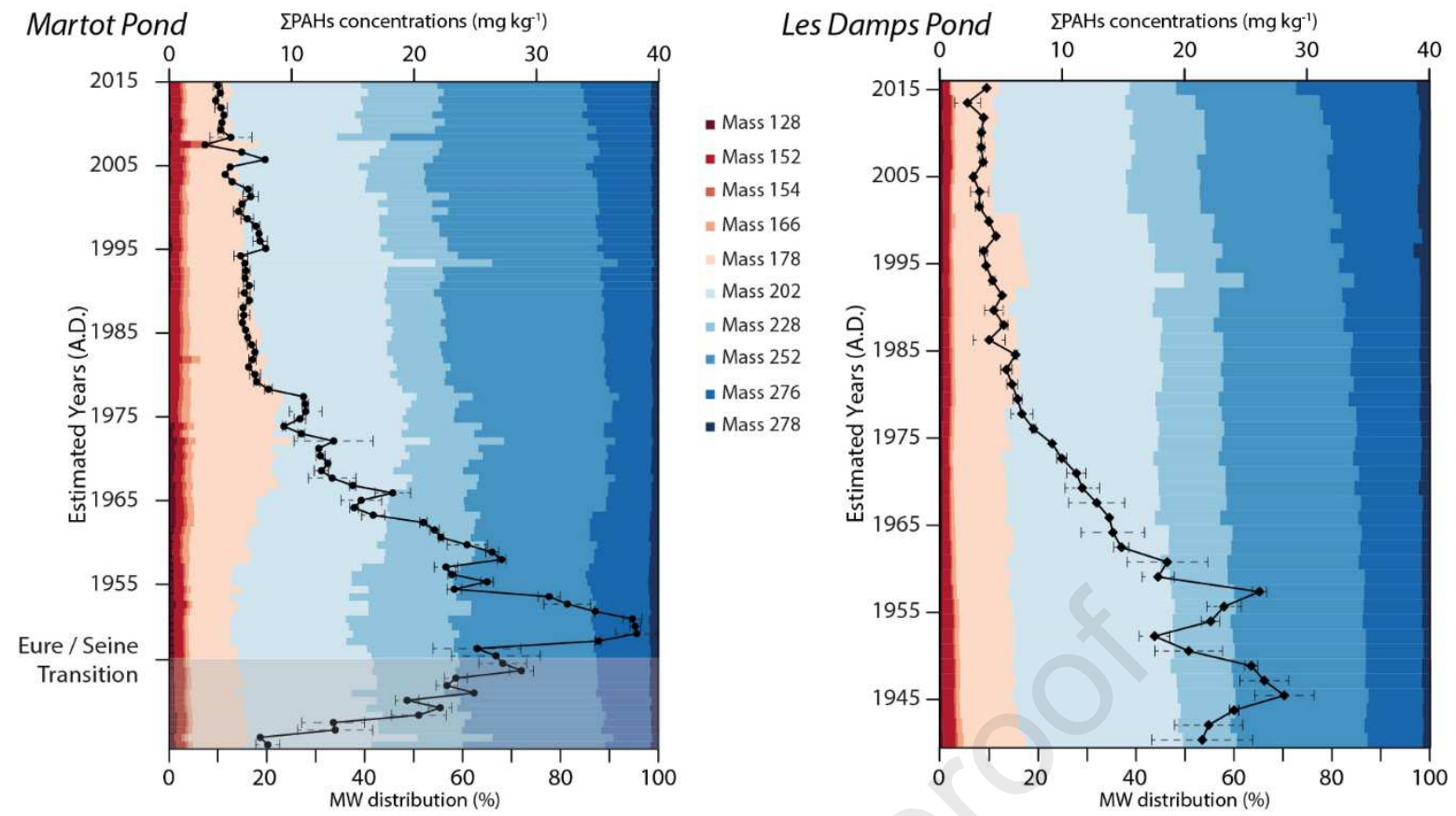

Figure 4. PAH concentrations $\left(\mathrm{mg} \mathrm{kg}^{-1}\right.$ ) and molar weight (MW) distribution (\%) in Martot Pond (MAR16-02 core) and Damps Pond (DAM17-02 core). 

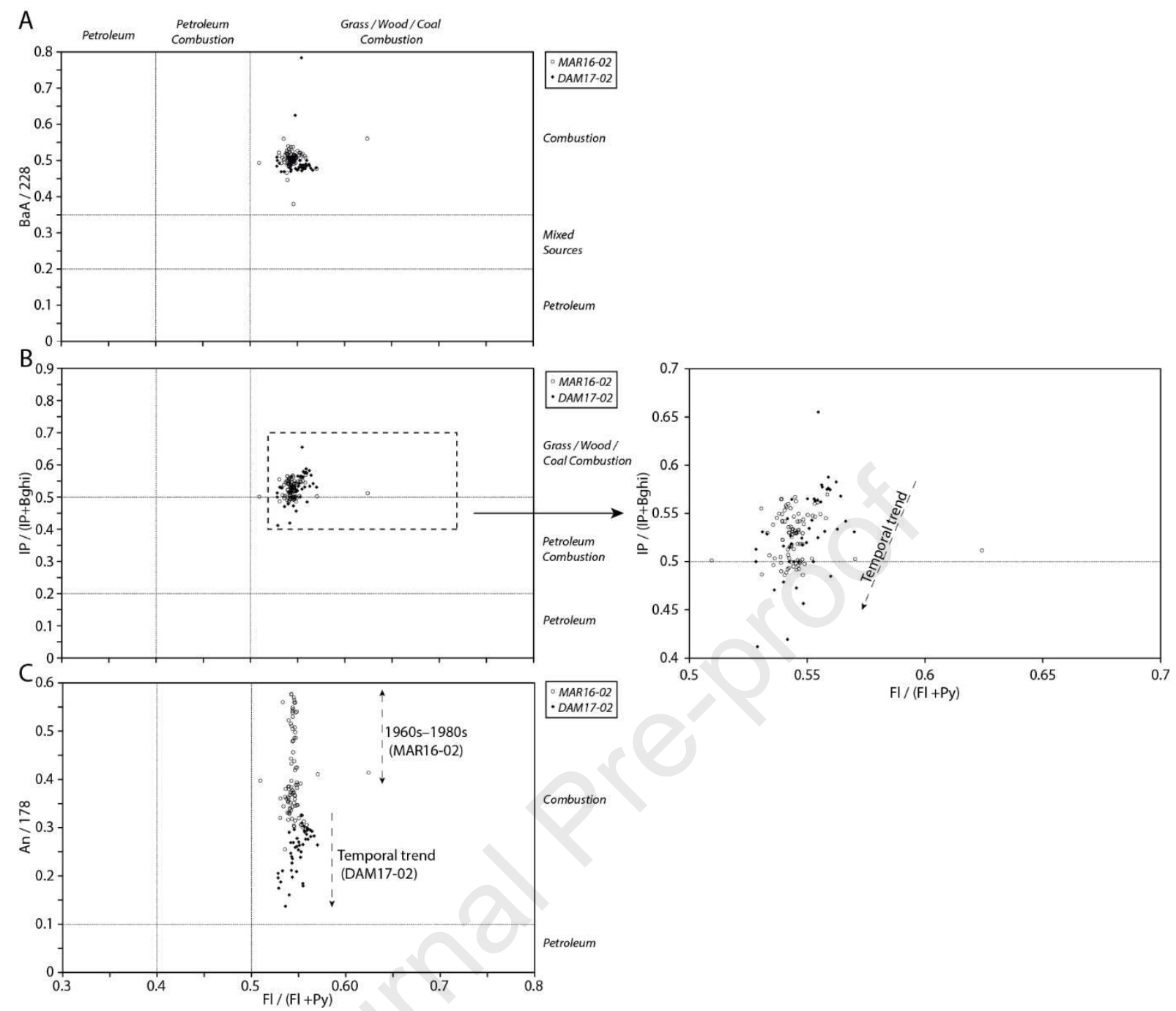

Figure 5. $\mathrm{PAH}$ diagnostic ratios $\mathrm{A}$. $\mathrm{BaA} / 228$ vs $\mathrm{Fl} /(\mathrm{Fl}+\mathrm{Py})$; $\mathrm{B}$. IP/(IP+Bghi) vs $\mathrm{Fl} /(\mathrm{Fl}+\mathrm{Py})$ and $\mathrm{C}$. $\mathrm{An} / 178$ vs $\mathrm{Fl} /(\mathrm{Fl}+\mathrm{Py})$ for the MAR16-02 (open circle) and DAM17-02 (black diamond) cores. 

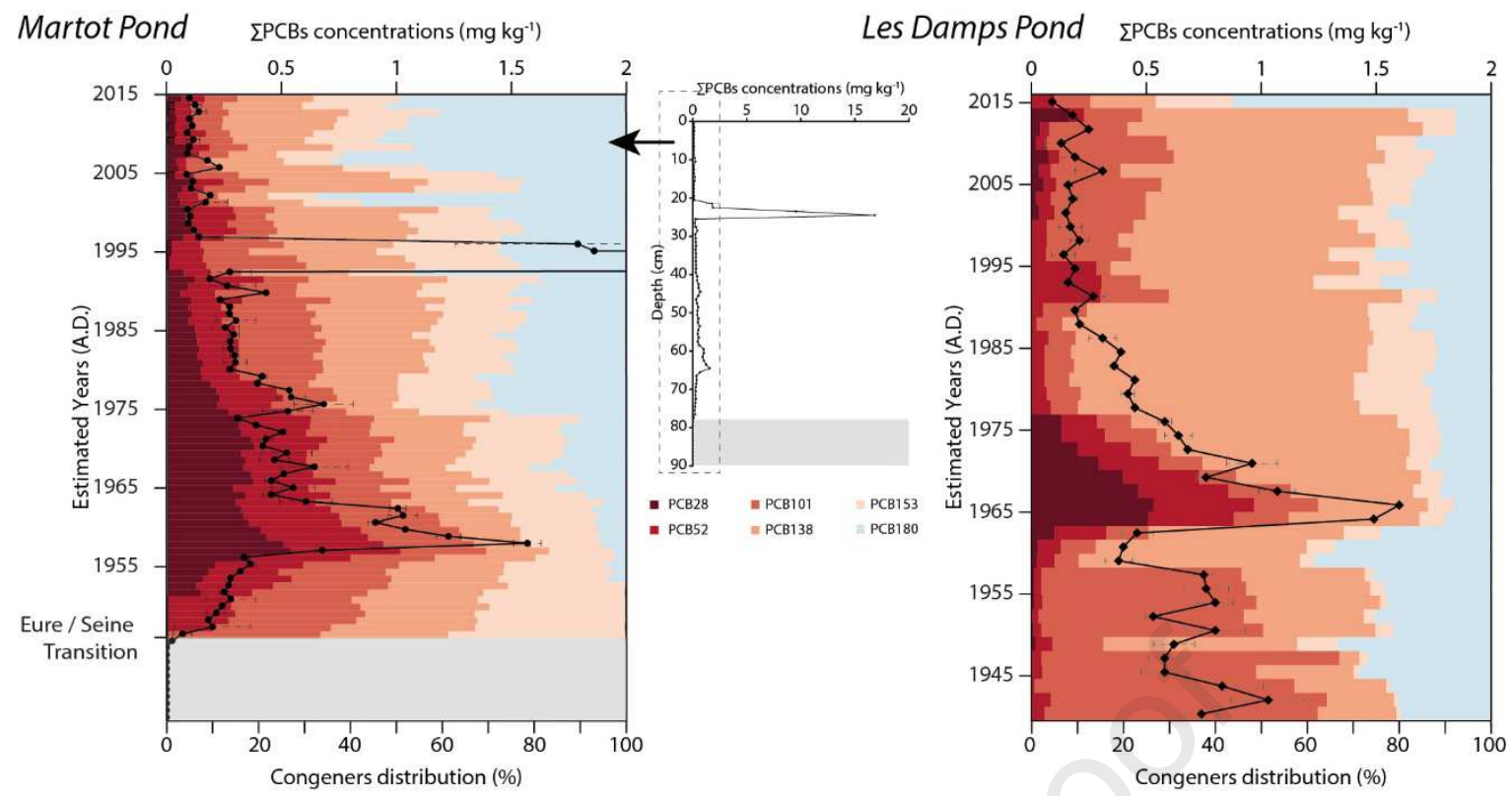

Figure 6. PCB concentrations and homolog distribution in Martot Pond (MAR16-02 core) and Les Damps Pond (DAM17-02 core).

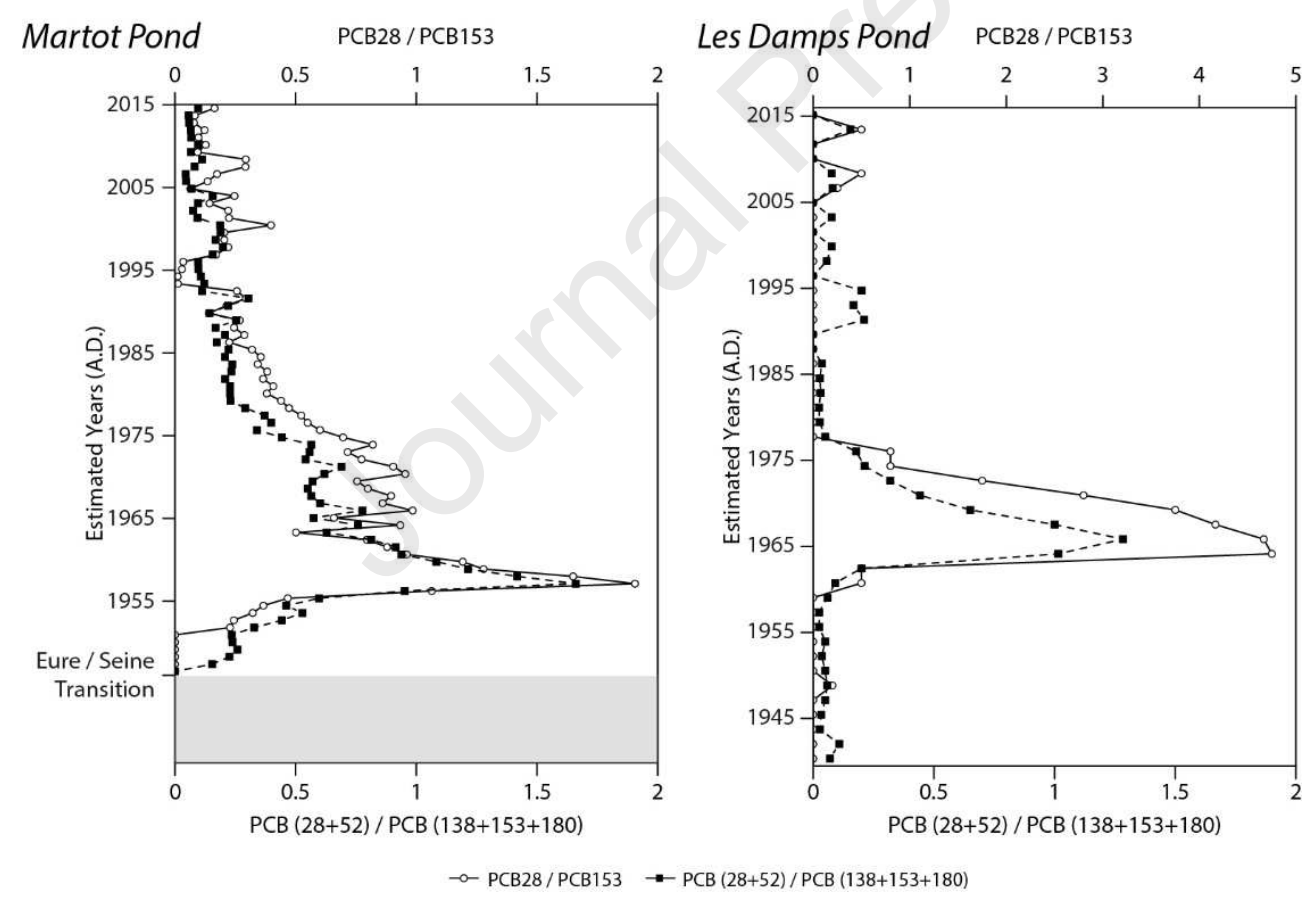

Figure 7. PCBs ratios in Martot Pond (MAR16-02 core) and Les Damps Pond (DAM17-02 core). 
- Temporal trends of PAHs and PCBs were reconstructed from sediment cores

- PAHs and PCBs showed a positive correlation with fine fractions

- PAHs showed a positive correlation with the refractory organic carbon

- PAHs were found to be predominantly of pyrogenic origin

- High levels of PCBs were linked to technical mixture discharges into the river 


\section{Declaration of interests}

$\bigotimes$ The authors declare that they have no known competing financial interests or personal relationships that could have appeared to influence the work reported in this paper.

$\square$ The authors declare the following financial interests/personal relationships which may be considered as potential competing interests: 